\title{
Wintering seabirds in south-west Greenland, 2017
}

\author{
Flemming Ravn Merkel',2, Kasper Lambert Johansen², Rasmus Due Nielsen², Ib Krag Petersen², \\ Jacob Sterup ${ }^{2}$ \& Anders Mosbech ${ }^{2}$
}

'Department of Birds \& Mammals, Greenland Institute of Natural Resources, Nuuk, Greenland;

${ }^{2}$ Department of Bioscience and Arctic Research Centre, Aarhus University, Aarhus, Denmark

\begin{abstract}
The South-west Greenland Open Water Area is an internationally important wintering area for seabirds in the North Atlantic. Nearly two decades after the area was last surveyed, we conducted a replicate aerial survey in March 2017 to update information on the distribution and abundance of seabirds. With a total effort of about $5800 \mathrm{~km}$, we covered the coastal area from Aasiaat $\left(69^{\circ} \mathrm{N}\right)$ to Kap Farvel $\left(60^{\circ} \mathrm{N}\right), 56 \%$ of the open water area in the fjords, and the offshore bank, Store Hellefiskebanke. Line transect survey methodology was used except in the fjords, which were censused by total counts. By means of distance sampling analyses, the abundances of the dominant species were estimated to be roughly 1100000 king eiders (Somateria spectabilis), 443000 common eiders (Somateria mollissima), 42000 long-tailed ducks (Clangula hyemalis) and 76000 Iceland gulls/glaucous gulls (Larus glaucoides/Larus hyperboreus). For the great black-backed gull (Larus marinus), great cormorant (Phalacrocorax carbo), mallard (Anas platyrhynchos) and red-breasted merganser (Mergus serrator), we present the first winter population estimates for the area $(6100,7700,7600$ and 3200 individuals, respectively). Areas around Kangaatsiaq, Nuuk and Julianehåbsbugten were identified as key wintering sites, as was Store Hellefiskebanke which held $99 \%$ of the king eiders. For all species assessed in 1999, abundance in the coastal survey area was considerably lower in 2017. In some cases, this may be due to changes in distribution patterns. However, for thick-billed murre (Uria lomvia), long-tailed duck and black-legged kittiwake (Rissa tridactyla), the reduced coastal abundances coincide with declining breeding populations.
\end{abstract}

To access the supplementary material, please visit the article landing page

\section{Introduction}

Seabirds provide important ecosystem services for Arctic communities by serving as food, playing a role in cultural identity and attracting tourist (Merkel \& Barry 2008; Huntington et al. 2013). In addition, they serve as an important link in the Arctic food web, where they transport nutrients from the oceans to coastal breeding areas (Green \& Elmberg 2014; Gonzalez-Bergonzoni et al. 2017). They are also strongly linked to the lower trophic levels of the marine ecosystem and recognized as important indicators of the state of their marine habitats (Cairns 1987; Piatt \& Sydeman 2007; Parsons et al. 2008). A number of seabird species have therefore been identified as priority species for monitoring ecosystem changes within the circumpolar Arctic (Irons et al. 2015; Kuletz et al. 2017). However, the distribution of

\section{Keywords}

International seabird wintering area; winter population status; distribution and abundance; seaducks; common eider; king eider

\section{Correspondence}

Flemming Ravn Merkel, Department of Bioscience, Aarhus University, Frederiksborgvej 399, 4000 Roskilde, Denmark. E-mail:frm@bios.au.dk

\section{Abbreviations}

Cl: confidence interval

GPS: global positioning system

MODIS Terra: Moderate Resolution Imaging

Spectroradiometer on the Terra satellite

seabirds during the non-breeding season has been identified as a significant knowledge gap, and more research on this topic has been recommended (Ganter \& Gaston 2013).

To provide further insight into the non-breeding season, we conducted an extensive aerial survey in southwest Greenland in the winter of 2017. The year-round open water area in south-west Greenland constitutes an internationally important wintering area for seabirds in the North Atlantic (Merkel et al. 2002). The coastal area, fjords and offshore areas in Davis Strait are especially important for seaducks and alcids, and are visited by birds breeding in the eastern Canadian Arctic, Greenland, Iceland, Norway and Russia (Lyngs 2003; Boertmann et al. 2006). However, two decades have passed since the area was last systematically surveyed, in 1999 (Merkel et al. 2002). In the meantime, evidence that especially 
piscivorous seabird species have declined in the eastern North Atlantic has accumulated (Frederiksen 2010; Ganter \& Gaston 2013; Kuletz et al. 2017). The declines appear to be linked to wide-ranging climate and ecosystem changes in the North Atlantic (Irons et al. 2008; Descamps et al. 2013; Frederiksen et al. 2013; Descamps et al. 2017). However, among planktonic and benthic feeders, some species are seemingly doing well and local changes are sometimes opposite to the general trend (Frederiksen 2017). At the same time, the winter harvest of several species of seabirds has declined considerably in the North Atlantic as a result of a combination of management regulations, urbanization and occupational changes (Merkel $\delta$ Barry 2008; Merkel et al. 2018). This may also have influenced seabird population development (Merkel 2010).

Here we report on the 2017 winter survey in southwest Greenland, aiming to update our knowledge of the distribution and abundance of seabirds in this internationally important wintering area. To a large degree, we replicated the design of the 1999 survey, but the survey coverage was slightly extended to include more fjords and the shallow-water offshore bank, Store Hellefiskebanke. In addition, we included systematic records of mallard, red-breasted merganser, great black-backed gull and glaucous/Iceland gull, and for these species, we present the first winter population estimates for south-west Greenland. As in 1999, our main focus was the coastal area and the fjords, so that highly pelagic species were only partially covered by the survey. To the extent possible, we compare winter population estimates between 1999 and 2017 to detect changes over time, and for convenience, we have included some information from 1999 in the Materials and methods and Results sections.

\section{Materials and methods}

\section{Survey area and design}

The study area is part of the year-round open water area along south-west Greenland (Fig. 1), created by a warm-water branch-the Irminger Current—of the North Atlantic Current and referred to as the south-west Greenland Open Water Area (see Valeur et al. 1996; Merkel et al. 2002). Within the coastal survey area from Aasiat in the north $\left(68^{\circ} 38^{\prime} \mathrm{N}\right)$ to Kap Farvel $\left(59^{\circ} 40^{\prime} \mathrm{N}\right)$ in the south, a double set of zigzag transects was assigned in 1999 (Merkel et al. 2002), and we used the exact same transect system and survey area in 2017 (Fig. 2). The coastal survey area, covering $22250 \mathrm{~km}^{2}$, largely includes all waters less than $50 \mathrm{~m}$ deep (except for the $<50 \mathrm{~m}$ deep offshore banks), but because of complex bathymetry many areas with depths $>50 \mathrm{~m}$ are also covered. We focussed on full coverage of waters $<50 \mathrm{~m}$ deep because this encompasses the maximum dive depth and habitat of the benthic feeding common eiders and king eiders (Guillemette et al. 1993; Mosbech, Danø et al. 2006), which are the two most abundant species in the area. All marine areas located east of the coastal survey area are referred to as fjords. For the 2017 survey, additional transects were planned to cover the offshore banks, Store Hellefiskebanke and Fyllas Banke.

Survey altitude and ground speed were $76 \mathrm{~m}$ and 150 $170 \mathrm{~km} / \mathrm{hr}$ in the coastal survey area and on the offshore banks, and approximately $320 \mathrm{~m}$ and 150-250 km/hr in the fjords (identical to 1999 survey). The higher survey altitude in the fjords was chosen to allow us to cover each fjord (by means of total counting) in just a single overflight following the centreline of the fjord. This eliminates the risk of double counting, which arises when two overflights (following each side of the fjord) are needed for full coverage. The higher survey altitude still allowed for the efficient detection of common eiders, as they were typically aggregated in large flocks at some distance from the coast (Merkel \& Mosbech 2008). However, in case of suboptimal sea state and visibility, each side of the fjord was surveyed separately at a lower survey altitude.

\section{Survey procedures}

Data were collected from a Twin Otter (TF-NLO) aircraft. Two bird observers, one on each side of the plane, were seated by bubble windows, which allowed observation of the area below the plane and outwards. They recorded their observations and the corresponding time on tape recorders. GPS position and time were logged by two GPS units every 6 seconds or less, and sightings were subsequently georeferenced on the basis of their time of recording. Information about visibility, sea state and ice cover was recorded at the starting point of each transect and whenever conditions changed.

Survey in the coastal survey area and on the offshore banks was conducted according to the line transect methodology (Buckland et al. 1993). Sightings (flocks of birds) were recorded once they were perpendicular to the plane and were assigned to one of four distance bands: (1) $44-163 \mathrm{~m}\left(60-25^{\circ}\right)$, (2) $163-431 \mathrm{~m}\left(25-10^{\circ}\right)$, (3) 431-

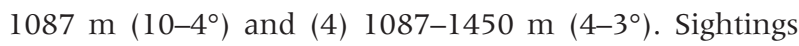
directly underneath the plane and outwards to $60^{\circ}$ were not recorded $(0-44 \mathrm{~m})$. This procedure differs slightly from the method used in 1999, when exact perpendicular distances to a subset of sightings were measured using an inclinometer. As the use of distance bands was much faster, this left sufficient time to record distances for all sightings in 2017 and to include a number of species that were not recorded in 1999. All survey activity in fjords was conducted as total count survey, and only information about species and flock size was systematically recorded. 
Fig. 1 (right). Satellite image from MODIS Terra showing the ice cover in south-west Greenland and Davis Strait on 8 March 2017 (https://worldview. earthdata.nasa.gov).
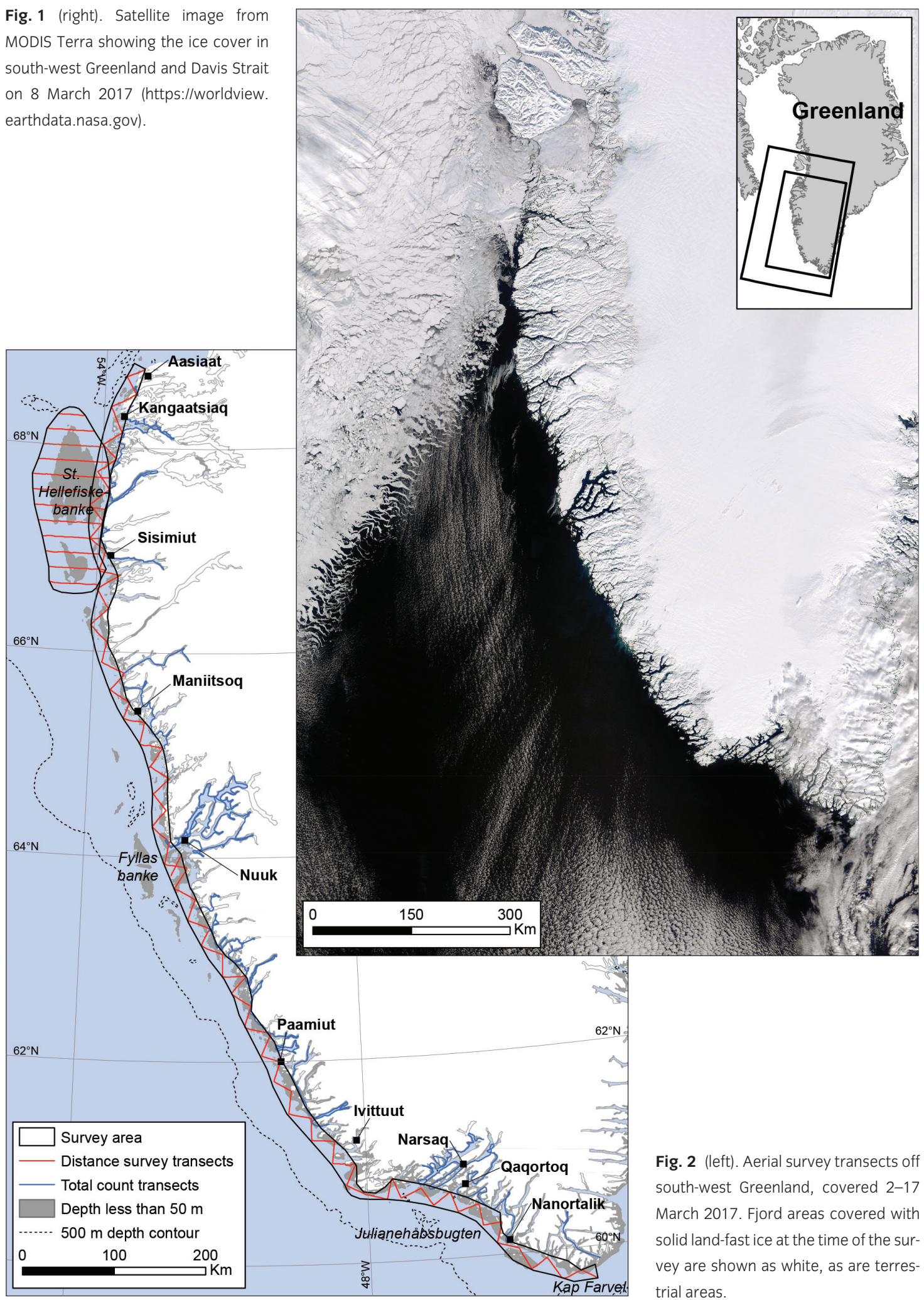

nd 
Table 1 Observations_sightings (S) and individuals (I)_of bird species during the aerial survey off south-west Greenland, 2-17 March 2017.

\begin{tabular}{|c|c|c|c|c|c|c|c|c|}
\hline & \multicolumn{2}{|c|}{ Coast } & \multicolumn{2}{|c|}{ Bank } & \multicolumn{2}{|c|}{ Fjord } & \multicolumn{2}{|c|}{ Total } \\
\hline & $S$ & 1 & $\mathrm{~S}$ & I & $\mathrm{S}$ & 1 & $\mathrm{~S}$ & 1 \\
\hline Northern fulmar (Fulmaris glacialis) & 1 & 3 & & & & & 1 & 3 \\
\hline Great cormorant (Phalacrocorax carbo) & 48 & 274 & & & 67 & 374 & 115 & 648 \\
\hline King eider (Somateria spectabilis) & 231 & 3945 & 143 & 200077 & 37 & 1158 & 411 & 205180 \\
\hline Common eider (Somateria mollissima) & 1846 & 19694 & 24 & 434 & 1734 & 211025 & 3604 & 231153 \\
\hline Harlequin duck (Histrionicus histrionicus) & 3 & 7 & & & 1 & 2 & 4 & 9 \\
\hline Long-tailed duck (Clangula hyemalis) & 380 & 1981 & 5 & 90 & 124 & 1746 & 509 & 3817 \\
\hline Red-breasted merganser (Mergus serrator) & 28 & 93 & & & 209 & 1356 & 237 & 1449 \\
\hline Black-legged kittiwake (Rissa tridactyla) & 1 & 1 & & & & & 1 & 1 \\
\hline White gulls (L. glaucoides + L. hyperboreus) & 598 & 2888 & 77 & 224 & 578 & 10522 & 1253 & 13634 \\
\hline Great black-backed gull (Larus marinus) & 179 & 209 & 6 & 7 & 172 & 620 & 357 & 836 \\
\hline Black guillemot (Cepphus grylle) & 87 & 316 & 49 & 236 & 6 & 16 & 142 & 568 \\
\hline Other bird species & & & & & & & 0 & 0 \\
\hline Canada goose (Branta canadensis) & 1 & 3 & & & & & 1 & 3 \\
\hline Mallard (Anas platyrhynchos) & 37 & 358 & & & 180 & 1821 & 217 & 2179 \\
\hline Purple sandpiper (Calidris maritima) & 11 & 210 & & & 26 & 209 & 37 & 419 \\
\hline White-tailed eagle (Haliaeetus albicilla) & 5 & 5 & & & 33 & 38 & 38 & 43 \\
\hline
\end{tabular}

Most sightings were identifiable at species level (Table 1). However, all large alcids, except for black guillemots, were recorded as thick-billed murres. This is the most common large alcid in south-west Greenland, but relatively small numbers of razorbills (Alca torda) and common murres (Uria aalge) are also known to winter here and may have been misclassified as thick-billed murres. Glaucous and Iceland gulls were also lumped together due to difficulties in separating these species at a distance.

\section{Abundance estimates}

We used distance sampling analysis (Buckland et al. 2001, 2004) to estimate the abundance of 10 bird species within the coastal survey area and three species in the Store Hellefiskebanke survey area. These estimates were added to the total count numbers from the fjords to get a total estimate for the study area. We followed the analytical procedures used for the 1999 survey as closely as possible (see Merkel et al. 2002), allowing for differences between the present data set and the 1999 data set and subsequent advances in methods (e.g., multi-covariates distance sampling). In short, we used the software Distance 7.1 (Thomas et al. 2010) to fit detection functions for the different species. In the field, data were left truncated at $44 \mathrm{~m}$, and during analysis, the outermost distance band (1087-1450 m) was right truncated in most cases because of few or no sightings. Uniform, half-normal and hazard-rate key functions with cosine, simple polynomial or Hermite polynomial series expansion were evaluated, and the most parsimonious model was chosen on the basis of Akaike information criterion. Observer was tested as covariate in all cases. If the regression of $\ln$ (flock size) against estimated $g(x)$ (detection probability at distance $\mathrm{x}$ ) was significant at the 5\% level, we used expected (predicted) flock size in the abundance calculations to avoid bias from smaller flocks being missed more frequently than larger flocks at large distances; otherwise, the mean observed flock size was used (Buckland et al. 2001: 128-129). However, in cases with a large range in flock size, and/or where mean and expected flock size differed substantially, we post-stratified the data set by flock size prior to distance analysis and subsequently summed the sub-estimates. Very large flocks of common eiders ( $\geq 100$ individuals) and king eiders ( $\geq 250$ individuals) were analysed as strip census data, assuming $100 \%$ detection efficiency within the three innermost distance bands (44-1087 m). Sub-area estimates were based exclusively on data from these areas, except for black guillemot, for which a global detection function and a flock size estimate (but separate sighting rates) were used for the coastal survey area and Store Hellefiskebanke because of insufficient sample size in the latter area. In the abundance estimates for king eider and black guillemot within the coastal survey area, we used a global detection function and a flock size estimate but calculated separate sighting rates north and south of Nuuk on account of very different sighting frequencies (referred to as "coastal, north" and "coastal, south"). The resulting abundance estimates are summarized in Tables 2 and 3, whereas detailed information on individual parameter values in the abundance calculations is reported in Supplementary Tables S1 and S2. 
Table 2 Abundance estimates of wintering seabird populations in south-west Greenland, March 2017, as a result of distance sampling analyses (see details in Supplementary Table S1) within the coastal survey area and on the offshore bank Store Hellefiskebanke (St. HFB). Fjords were covered as total count surveys. Estimates from a similar survey in 1999 are also shown (Merkel et al. 2002). For direct comparison please note the conditions mentioned in the discussion.

\begin{tabular}{|c|c|c|c|c|c|c|}
\hline \multirow{2}{*}{ Species and stratum } & \multicolumn{3}{|c|}{$\begin{array}{l}\text { Abundance estimate } 2017 \\
\qquad 95 \% \mathrm{Cl}\end{array}$} & \multicolumn{3}{|c|}{$\begin{array}{l}\text { Abundance estimate } 1999 \\
\qquad 95 \% \mathrm{Cl}\end{array}$} \\
\hline & $N$ & Lower & Upper & $N$ & Lower & Upper \\
\hline \multicolumn{7}{|l|}{ Common eider } \\
\hline Coastal, $S<10$ & 94962 & 77817 & 115886 & 92326 & 75701 & 112603 \\
\hline Coastal, $10 \leq \mathrm{S}<100$ & 112373 & 85389 & 147885 & 130134 & 100862 & 167903 \\
\hline Coastal, $S \geq 100$ & 24315 & 11380 & 51954 & 136500 & 53273 & 349747 \\
\hline Coastal, total & 231651 & 194065 & 276517 & 358960 & 243025 & 530202 \\
\hline Fjords & 211025 & - & - & 103834 & - & - \\
\hline Total & 442676 & 405090 & 487542 & 462794 & 341573 & 627036 \\
\hline \multicolumn{7}{|l|}{ King eider } \\
\hline Coastal, north & 20110 & 13015 & 31074 & & & \\
\hline Coastal, south & 579 & 239 & 1402 & & & \\
\hline Coastal, total & 20689 & 13539 & 31615 & 149317 & 52838 & 421957 \\
\hline Fjords & 1158 & - & - & 3584 & - & - \\
\hline St. HFB, $\mathrm{S}<250$ & 35091 & 15321 & 80374 & & & \\
\hline St. HFB, $S \geq 250$ & 1043670 & 445988 & 2442324 & & & \\
\hline St. HFB (excl. coastal zone) & 1078761 & 472611 & 2462334 & Not surveyed & & \\
\hline Total & 1092705 & 479405 & 2487204 & & & \\
\hline \multicolumn{7}{|l|}{ Long-tailed duck } \\
\hline Coastal, $\mathrm{S}<5$ & 15271 & 10945 & 21308 & & & \\
\hline Coastal, $S \geq 5$ & 24555 & 15997 & 37692 & & & \\
\hline Coastal, total & 39826 & 29650 & 53495 & 94382 & 66943 & 133070 \\
\hline Fjords & 1746 & - & - & 17 & & \\
\hline Total & 41572 & 31396 & 55241 & 94399 & 66960 & 133087 \\
\hline \multicolumn{7}{|l|}{ Thicked-billed murre } \\
\hline Coastal & 1821 & 1014 & 3271 & 125439 & 78091 & 201497 \\
\hline Fjords & 0 & & & 215 & & \\
\hline \multicolumn{7}{|l|}{ Black guillemot } \\
\hline Coastal (north) & 4657 & 2174 & 9973 & 12030 & 5335 & 27128 \\
\hline St. HFB & 601 & 302 & 1196 & Not surveyed & & \\
\hline Fjords & 16 & - & - & 69 & & \\
\hline Total & 5274 & 2669 & 10437 & 12099 & 5404 & 27197 \\
\hline \multicolumn{7}{|l|}{ Gl. gull + Icel. gull } \\
\hline Coastal, north & 53009 & 28314 & 99241 & Not recorded & & \\
\hline Coastal, south & 9760 & 6230 & 15289 & Not recorded & & \\
\hline St. HFB & 2734 & 678 & 11033 & Not recorded & & \\
\hline Fjords & 10522 & & & Not recorded & & \\
\hline Total & 76025 & 45744 & 136085 & & & \\
\hline \multicolumn{7}{|l|}{ Great black-backed gull } \\
\hline Coastal & 5491 & 4275 & 7053 & Not recorded & & \\
\hline Fjords & 620 & & & & & \\
\hline Total & 6111 & 4895 & 7673 & & & \\
\hline \multicolumn{7}{|l|}{ Great cormorant } \\
\hline Coastal & 7327 & 3651 & 14703 & Not recorded & & \\
\hline Fjords & 374 & & & & & \\
\hline Total & 7701 & 4025 & 15077 & & & \\
\hline \multicolumn{7}{|l|}{ Mallard } \\
\hline Coastal & 5785 & 2880 & 11621 & Not recorded & & \\
\hline Fjords & 1821 & & & Not recorded & & \\
\hline Total & 7606 & 4701 & 13442 & & & \\
\hline \multicolumn{7}{|l|}{ Red-breasted merganser } \\
\hline Coastal & 1843 & 910 & 3731 & Not recorded & & \\
\hline Fjords & 1356 & & & Not recorded & & \\
\hline Total & 3199 & 2266 & 5087 & & & \\
\hline
\end{tabular}




\section{Distribution maps}

To produce overview maps of the distribution of the different species, we split all transects in segments of $2 \mathrm{~km}$ and calculated a species-specific density for each segment on the basis of the number of individuals observed along the segment, the length of the segment and the effective search width (see Buckland et al. 2001) of the species determined in course of the distance sampling analyses (see Supplementary Table 1 for the effective search widths used). The segment densities were then subjected to inverse distance weighted interpolation (search radius: $6 \mathrm{~km}$; power: 2; output cell size: $1 \mathrm{~km}$ ) using the Spatial Analyst extension of ArcGIS 10.3 (ESRI, USA). This mapping procedure is comparable to that used for the 1999 survey (Merkel et al. 2002). As true effective search widths are not available from the fjords (total count survey) and we used effective search widths estimated from the coastal survey area here, we expect fjord densities to be slightly inflated in the maps. Solid land-fast ice in the fjords at the time of the survey was digitized on the basis of (MODIS Terra) satellite images (https://worldview.earthdata.nasa.gov) and is shown in white in Figs. 2-12.

\section{Results}

\section{Effort and ice cover}

During the fieldwork period of 28 February-20 March 2017, weather conditions allowed seven survey days: 2 , 3, 6, 9, 15, 16 and 17 March. With a total effort of 1825 $\mathrm{km}$, the entire coastal survey area was covered once, corresponding to one set of the zigzag transects (Fig. 2). This is a smaller line transect effort than in 1999 (2863 $\mathrm{km}$ ), when most of the second set of the zigzag transects were also surveyed. The largest offshore bank in the area, Store Hellefiskebanke, was also line transect surveyed in 2017 (784 km of effort), while weather prevented survey activity on Fyllas Banke. A total length of $3163 \mathrm{~km}$ was surveyed in the fjords. Assuming $3 \mathrm{~km}$ coverage on each side of the airplane, this corresponds to approximately $56 \%$ coverage of the open-water fjord area accessible to the birds at the time of the survey (areas not covered by solid land-fast ice). This, in turn, represents a larger total count effort than in 1999 (1798 $\mathrm{km}$ or about $43 \%$ of the open-water fjord area at the time of survey). The fjord effort in 2017 includes a complete coverage of the Nuuk fjord system, most of the Julianehåbsbugten (Julianehåb Bay), most of the fjords in the Kangaatsiaq area and many, but not all, fjords in between these areas (Fig. 2).

The coastal survey area was characterized by open water from around $66^{\circ} \mathrm{N}$ and south to Kap Farvel $\left(59^{\circ} 40^{\prime} \mathrm{N}\right)$, except for some minor concentrations of drifting brash ice just north of Nuuk. North of $66^{\circ} \mathrm{N}$, heavy pack ice from Davis Strait partly extended into the coastal survey area, so that ice cover fluctuated from little ice to almost full ice cover (Fig. 1). Prior to the survey, there was no open water north of $68^{\circ} \mathrm{N}$, but heavy wind on 26-27 February partly broke up the ice. The coastal ice situation was similar to that in 1999, although the pack ice in Davis Strait covered a larger proportion of the coastal survey area north of $66^{\circ} \mathrm{N}$ in 1999. Store Hellefiskebanke was fully covered by pack ice in 2017 and had only small leads and cracks of open water, except for the eastern part of the bank that overlaps the coastal survey area.

The ice situation in the fjords was also quite similar between 2017 and 1999. From a total fjord area of 17898 $\mathrm{km}^{2}$ (defined as the marine area east of the coastal survey area), 37\% was covered with land-fast ice in 2017, while $41 \%$ was covered with land-fast ice in 1999 . The largest differences between 2017 and 1999 occurred in the fjords of south-west Greenland between $60^{\circ} \mathrm{N}$ and $61^{\circ} \mathrm{N}$.

\section{General seabird distribution and dominant species}

A total of 17 bird species were recorded during the survey, of which 16 species were marine and 13 typically classified as seabird species. Sightings of these 17 species comprised a total of 3491 sightings (flocks) recorded on the coastal transects, 305 sightings on the offshore bank transects and 3167 sightings in the fjords (Table 1). We have mapped the spatial distribution for 10 of the most abundant species in Figs. 3-12: common eider, king eider, long-tailed duck, thick-billed murre, black guillemot, glaucous gull/Iceland gull, great black-backed gull, great cormorant, mallard and red-breasted merganser.

Within our survey area, most species had the highest density within the coastal areas or at the outer regions of the fjord systems. As measured by the number of sightings, the dominant species in the coastal area were common eider, glaucous gull/Iceland gull, long-tailed duck, king eider, great black-backed gull and black guillemot (Table 1, Figs. 3-12). In the fjords, common eider, glaucous gull/Iceland gull, red-breasted merganser, mallard, great black-backed gull and occasionally great cormorant were the dominant species (Table 1, Figs. 3-12). Whitetailed eagle (Haliaeetus albicilla) was relatively abundant in the Nuuk fjord system, around Frederikshåb Isblink $\left(62-63^{\circ} \mathrm{N}\right)$ and in the northern part of Julianehåbsbugten. On Store Hellefiskebanke, large numbers of king eiders were recorded.

Abundance was estimated for the same 10 bird species as mapped (Table 2). The sample size of the remaining 
Fig. 3 (right). Distribution and interpolated densities (see Materials and methods) of king eider (Somateria spectabilis) in south-west Greenland, 2-17 March 2017. Fjord areas covered with solid land-fast ice at the time of the survey are shown as white, as are terrestrial areas. A detailed map of Store Hellefiskebanke is shown in the top left corner, with king eider observations, observed ice cover (coloured lines) and shallow-water areas $<50$ m deep.

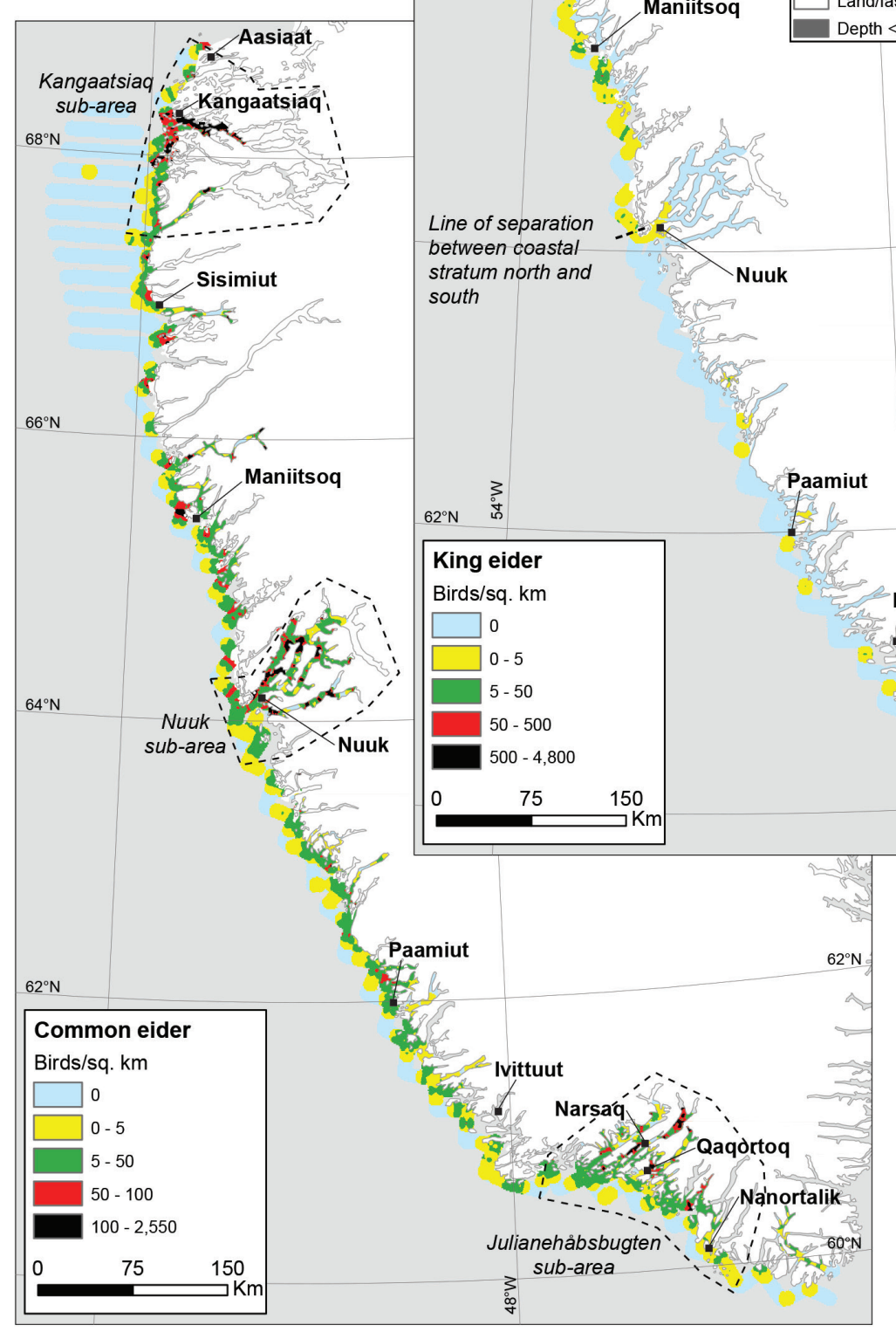

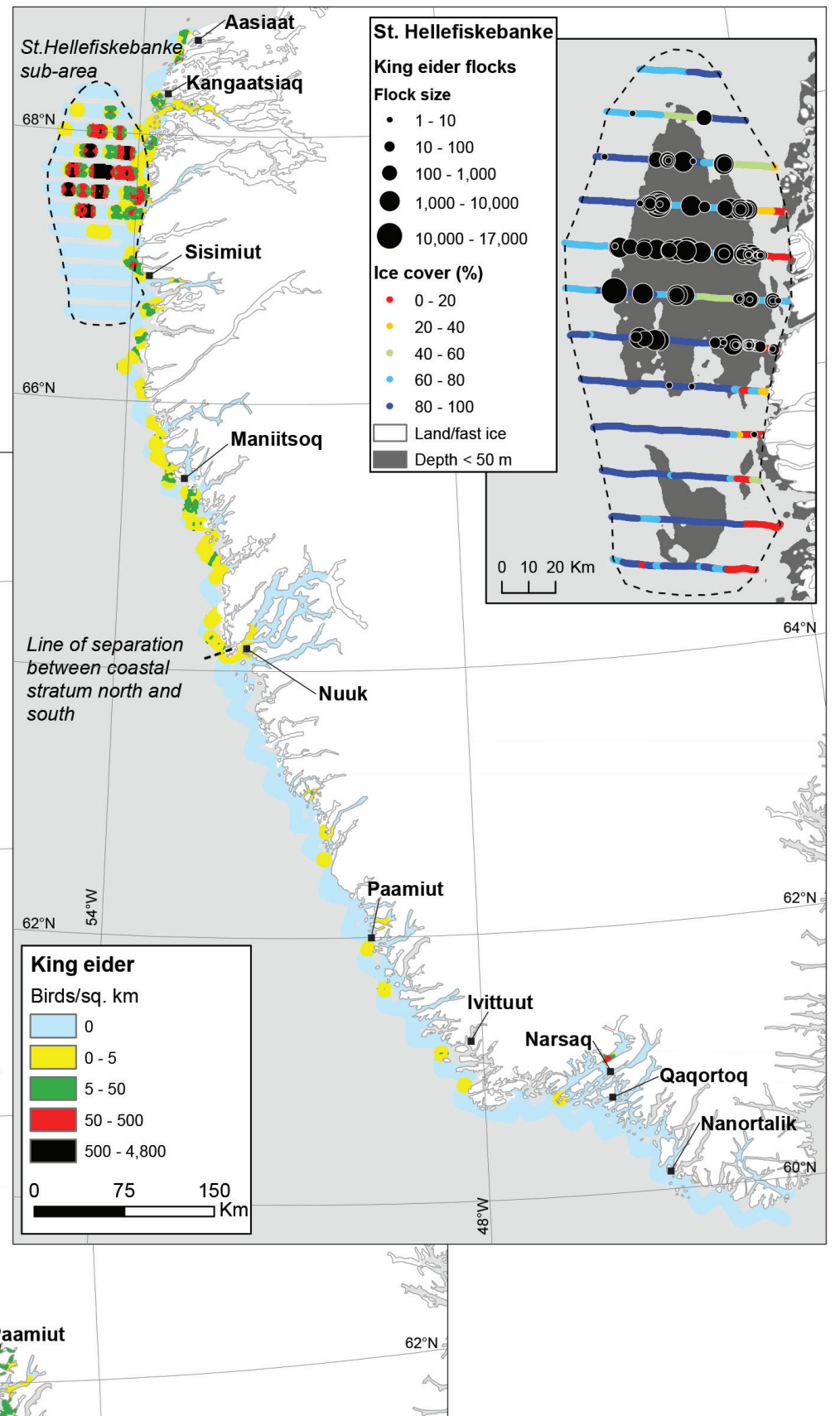

Fig. 4 (left). Distribution and interpolated densities (see Materials and methods) of common eider (Somateria mollissima) in south-west Greenland, 2-17 March 2017. Fjord areas covered with solid land-fast ice at the time of the survey are shown as white, as are terrestrial areas. 
Fig. 5 (right). Distribution and interpolated densities (see Materials and methods) of long-tailed duck (Clangula hyemalis) in south-west Greenland, 2-17 March 2017. Fjord areas covered with solid land-fast ice at the time of the survey are shown as white, as are terrestrial areas.

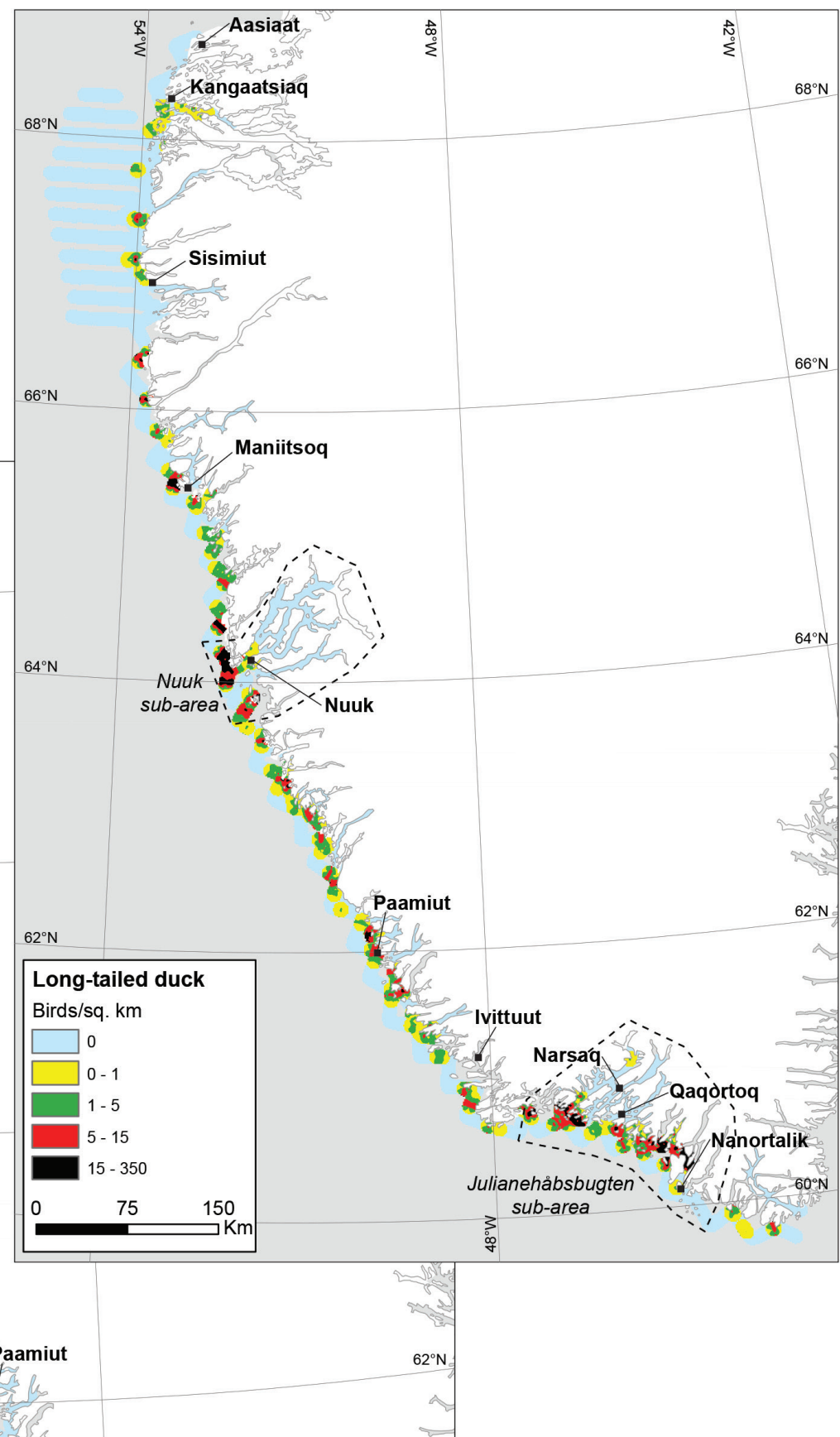

Fig. 6 (left). Distribution and interpolated densities (see Materials and methods) of thick-billed murre (Uria lomvia) in south-west Greenland, 2-17 March 2017. Fjord areas covered with solid land-fast ice at the time of the survey are shown as white, as are terrestrial areas. 
Fig. 7 (right). Distribution and interpolated densities (see Materials and methods) of black guillemot (Cepphus grylle) in south-west Greenland, 2-17 March 2017. Fjord areas covered with solid land-fast ice at the time of the survey are shown as white, as are terrestrial areas.

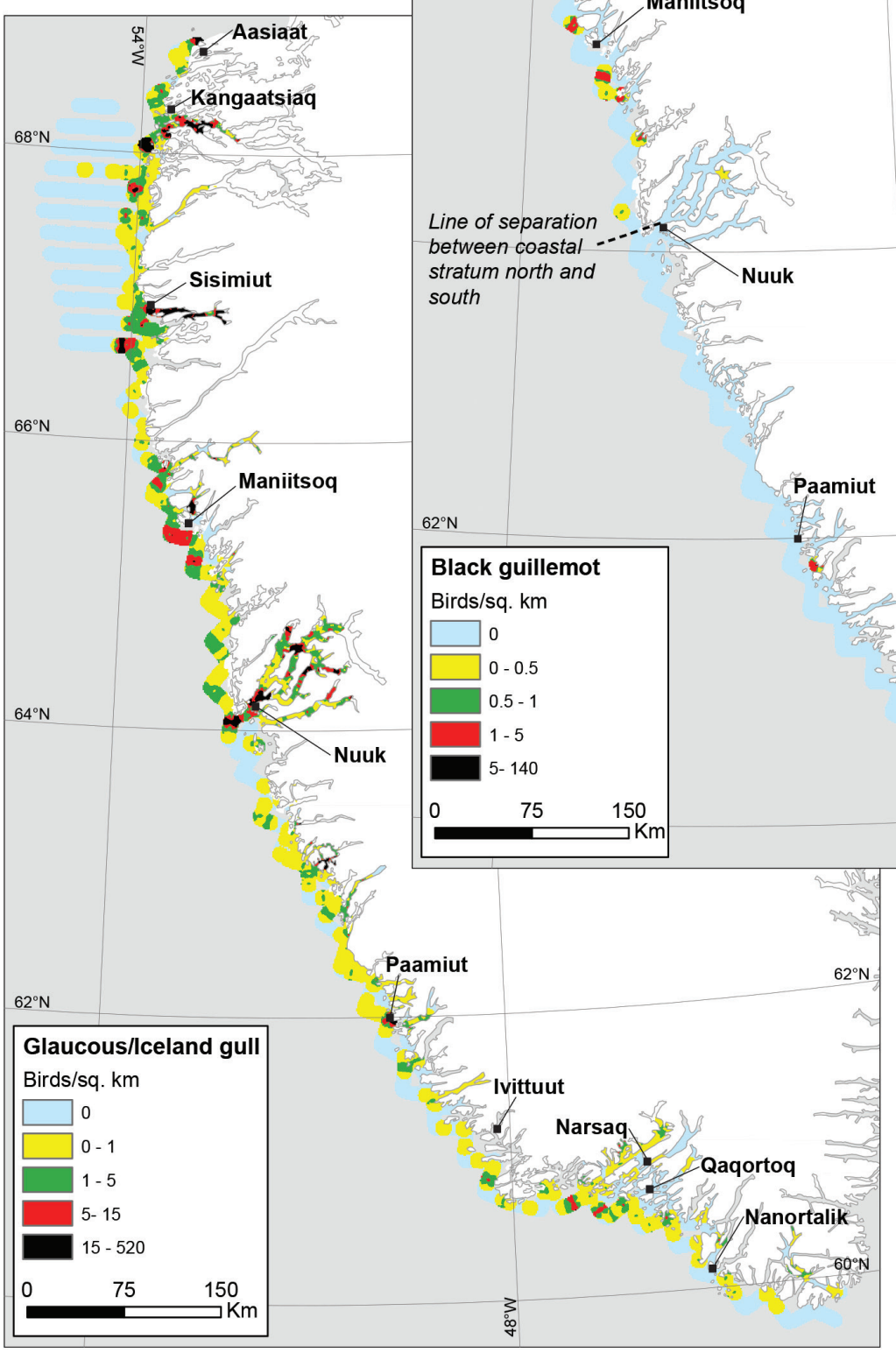

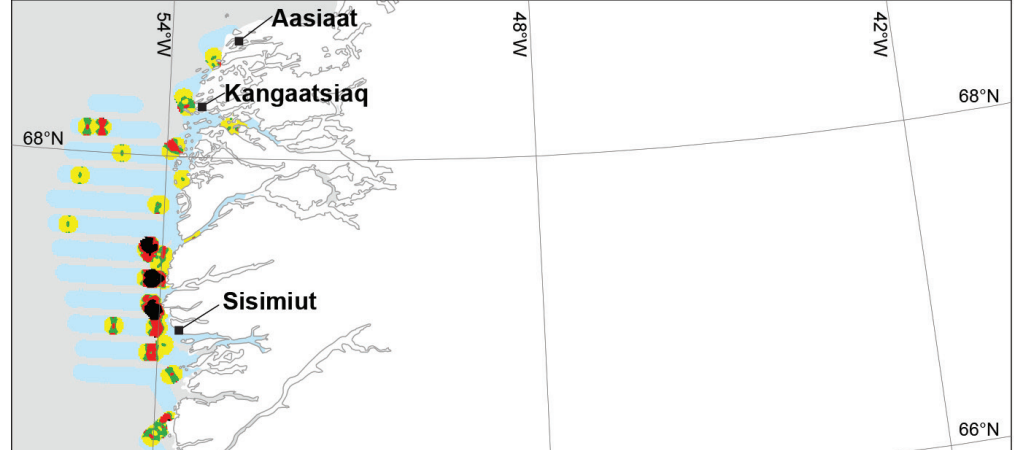

$66^{\circ} \mathrm{N}$

Fig. 8 (left). Combined distribution and interpolated densities (see Materials and methods) of glaucous gull (Larus hyperboreus) and Iceland gull (Larus glucoides) in south-west Greenland, 2-17 March 2017. Fjord areas covered with solid land-fast ice at the time of the survey are shown as white, as are terrestrial areas. 
Fig. 9 (right). Distribution and interpolated densities (see Materials and methods) of great black-backed gull (Larus marinus) in south-west Greenland, 2-17 March 2017. Fjord areas covered with solid land-fast ice at the time of the survey are shown as white, as are terrestrial areas.

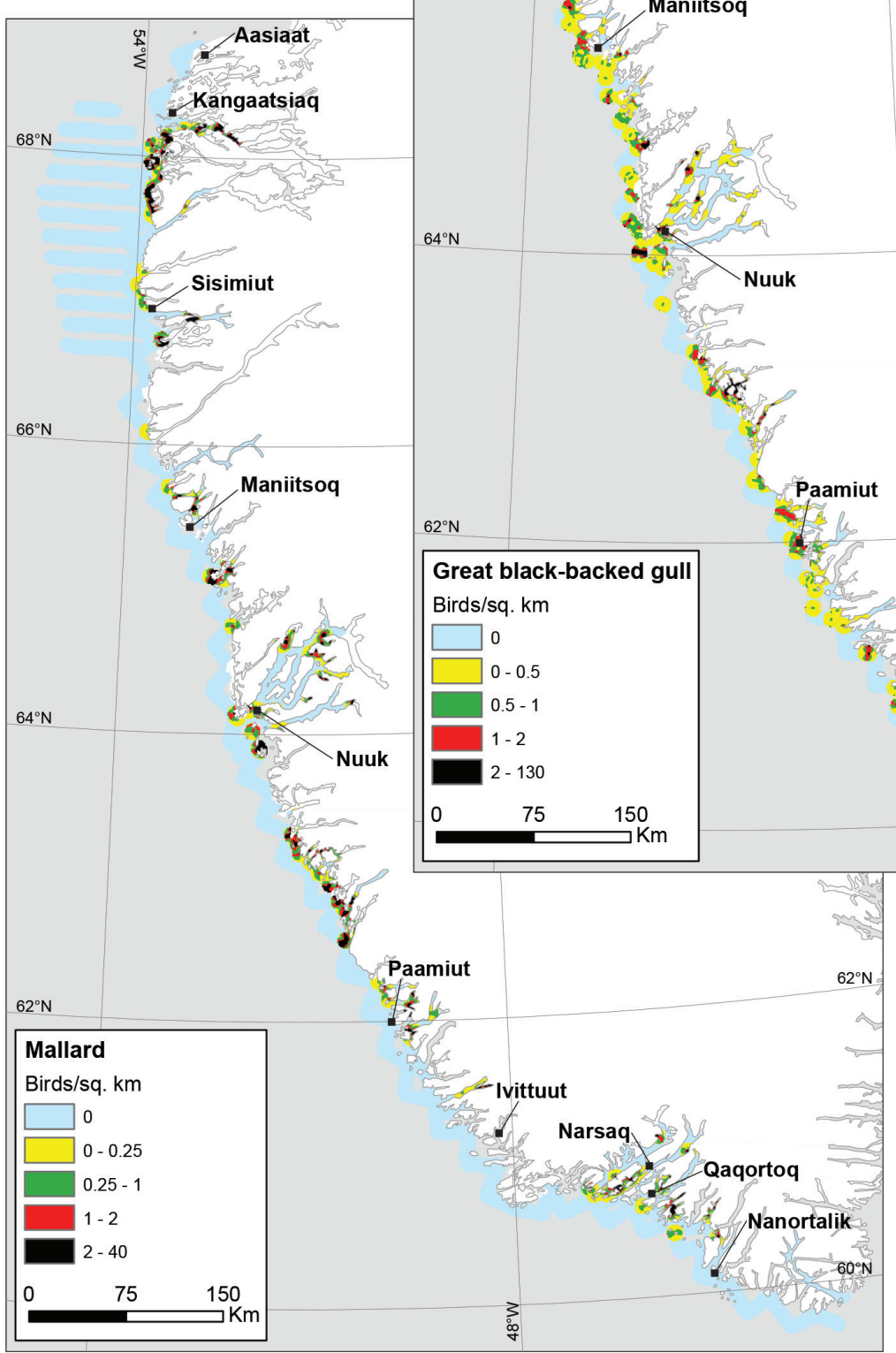

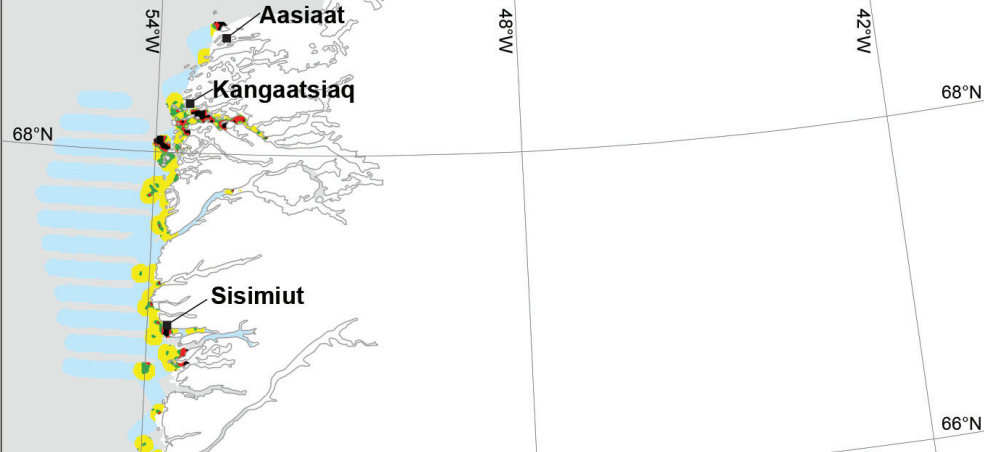

$66^{\circ} \mathrm{N}$ $6^{\circ} \mathrm{N}$ $4^{\circ} \mathrm{N}$

Fig. 10 (left). Distribution and interpolated densities (see Materials and methods) of mallard (Anas platyrhynchos) in south-west Greenland, 2-17 March 2017. Fjord areas covered with solid land-fast ice at the time of the survey are shown as white, as are terrestrial areas. 
Fig. 11 (right). Distribution and interpolated densities (see Materials and methods) of red-breasted merganser (Mergus serrator) in south-west Greenland, 2-17 March 2017. Fjord areas covered with solid land-fast ice at the time of the survey are shown as white, as are terrestrial areas.

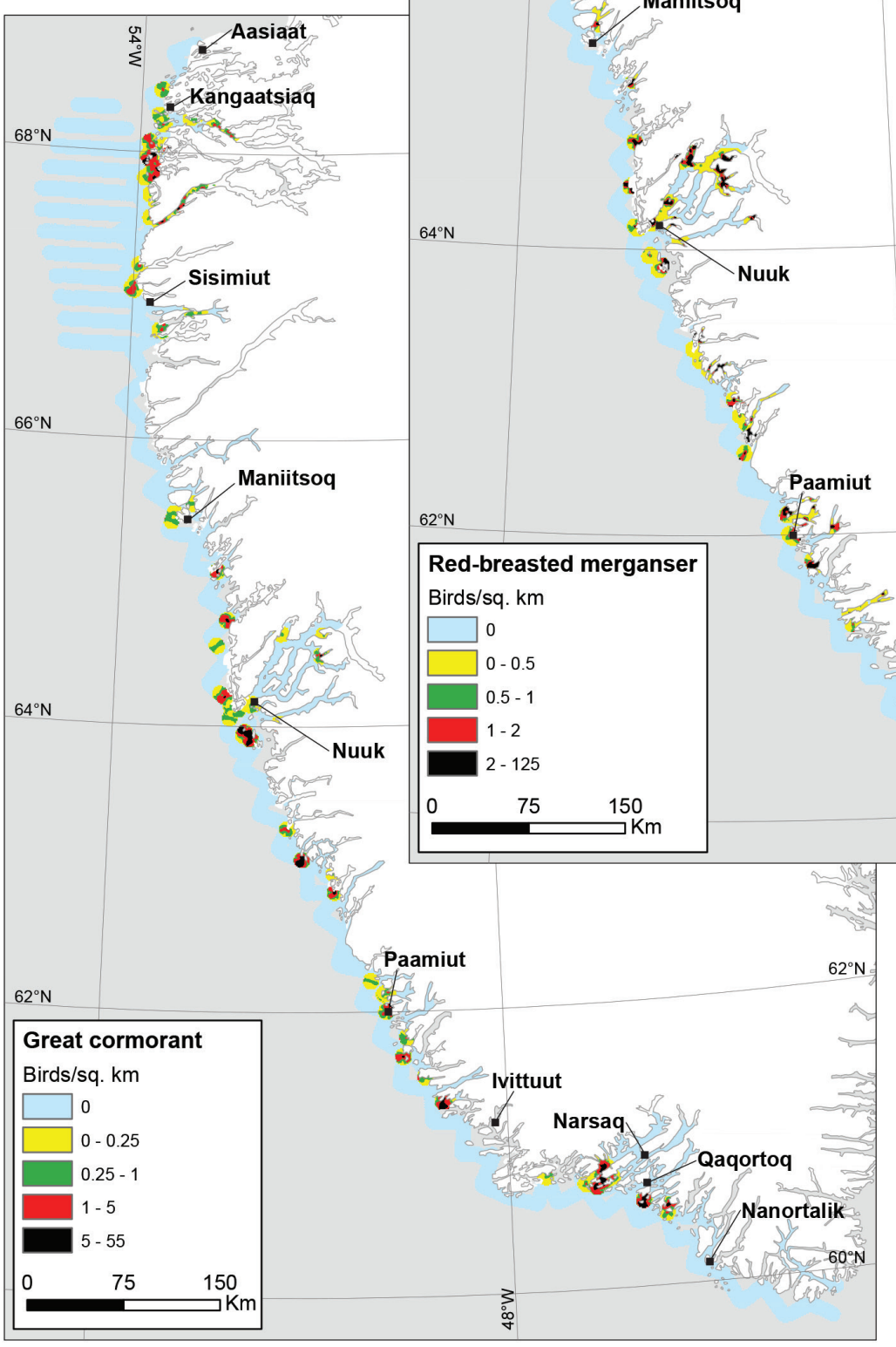

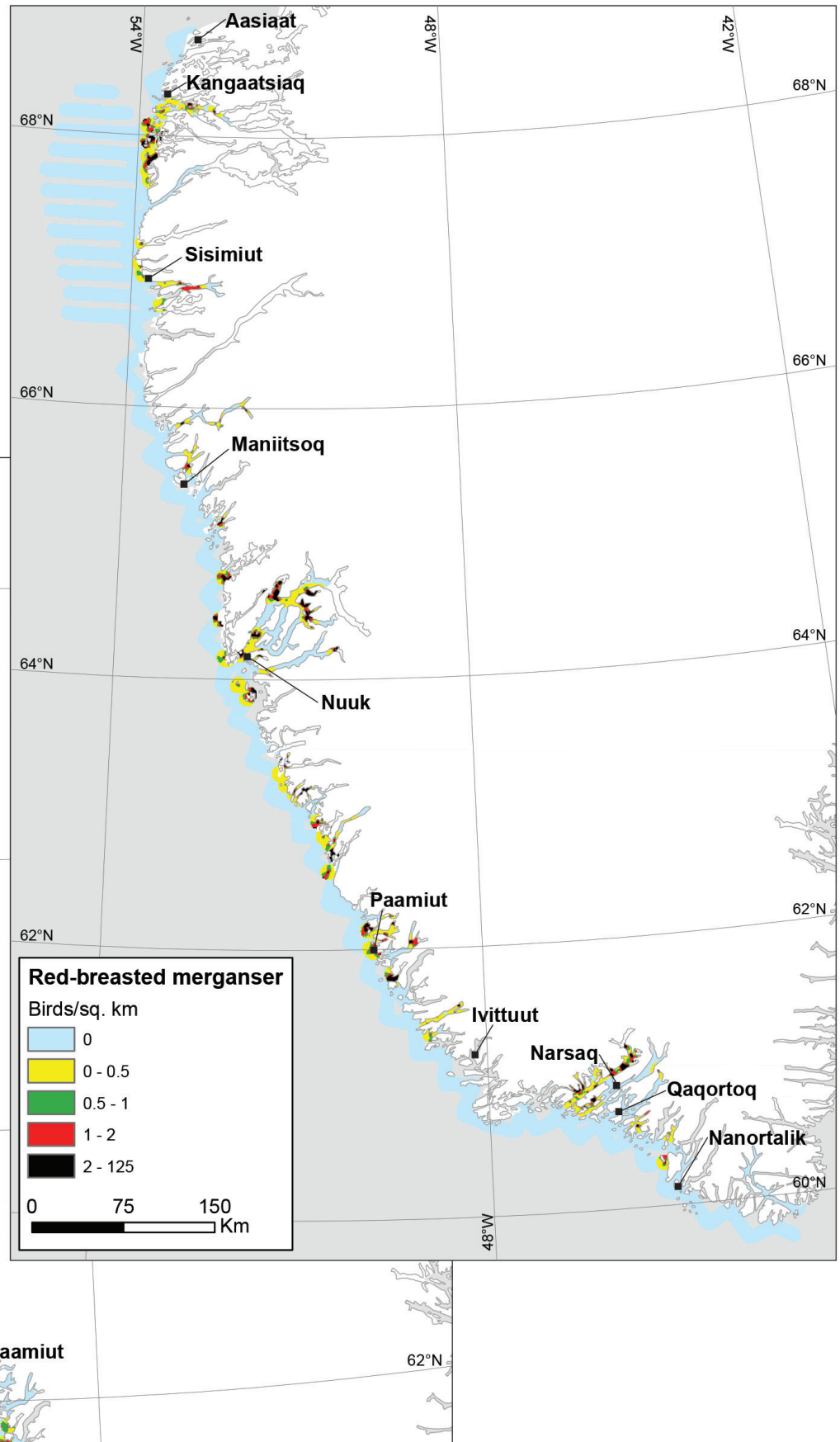

Fig. 12 (left). Distribution and interpolated densities (see Materials and methods) of great cormorant (Phalacrocorax carbo) in south-west Greenland, 2-17 March 2017. Fjord areas covered with solid land-fast ice at the time of the survey are shown as white, as are terrestrial areas. 
species was too low to allow distance sampling analyses (Table 1).

\section{King eider}

The total king eider winter population in the south-west Greenland was estimated to be 1092705 birds (95\% CI: 478405-2487204) in 2017, which makes this species the most abundant seabird within the study area. The heavily ice-packed offshore bank, Store Hellefiskebanke, was by far the most important wintering area for the king eider in 2017 (not surveyed in 1999), accounting for as much as $99 \%$ of the total abundance estimate (Table 2, Fig. 3). However, the large variation in flock size on Store Hellefiskebanke was also the main contributor to the wide CI of the abundance estimate (Supplementary Table S1). Birds aggregated in small leads and cracks in the pack ice (60-80\% ice cover) over the northern part of the bank, which constitutes the largest contiguous shallow water area $(<50 \mathrm{~m}$ ) on the bank (Fig. 3). Flocks of up to 17000 individuals were recorded.
In the coastal survey area, sighting rates were relatively high north of Nuuk, but flock sizes were small and the total abundance estimate for king eiders in the coastal survey area was only 20689 birds (95\% CI: 13539$31615)$. This is significantly fewer than the 149317 birds (95\% CI: 52 838-421957) estimated for the coastal survey area in 1999 (Table 2). The differences between the two years (1999 and 2017) were most striking south of Nuuk, where king eiders were almost absent in 2017 (Table 2, Fig. 3). In contrast to common eider, very few king eiders were observed in the fjords of south-west Greenland in 2017 and in 1999 (Table 1, Fig. 3).

A separate abundance estimate was calculated for Store Hellefiskebanke, including the eastern part of the bank, which overlaps the coastal survey area (Fig. 3, insert). This resulted in an estimate of 1107318 king eiders (95\% CI: 506 120-2422 653) for the entire Store Hellefiskebanke (Table 3 ). That this number is slightly higher than the total abundance estimate for all of southwest Greenland (Table 2) must be ascribed to the substantial uncertainty caused by the huge flock size variation

Table 3 Abundance estimates for key wintering sites in south-west Greenland (see species figures for boundaries) for common eider, king eider and longtailed duck, March 2017, as a result of distance sampling analyses (see details in Supplementary Table S2). Fjords were covered as total count surveys. Estimates from a similar survey in 1999 are also shown (Merkel et al. 2002). For direct comparison please note the conditions mentioned in the discussion.

\begin{tabular}{|c|c|c|c|c|c|c|}
\hline \multirow[t]{2}{*}{ Species and stratum } & \multicolumn{3}{|c|}{$\begin{array}{l}\text { Abundance estimate } 2017 \\
\qquad 95 \% \mathrm{Cl}\end{array}$} & \multicolumn{3}{|c|}{$\begin{array}{l}\text { Abundance estimate } 1999 \\
\qquad 95 \% \mathrm{Cl}\end{array}$} \\
\hline & $N$ & Lower & Upper & $N$ & Lower & Upper \\
\hline \multicolumn{7}{|l|}{ Common eider } \\
\hline Kangaatsiaq, coastal, $S<100$ & 30220 & 15837 & 57667 & & & \\
\hline Kangaatsiaq, coastal, S $\geq 100$ & 20899 & 8510 & 51326 & & & \\
\hline Kangaatsiaq, coastal, total & 51120 & 29756 & 87823 & NA & & \\
\hline Kangaatsiaq, fjords & 86755 & - & - & NA & - & - \\
\hline Kangaatsiaq, total & 137875 & 116511 & 174578 & & & \\
\hline Nuuk, coastal & 17555 & 9301 & 33132 & 24783 & 14664 & 41883 \\
\hline Nuuk, fjords & 68980 & - & - & 31952 & - & - \\
\hline Nuuk, total & 86535 & 78281 & 102112 & 56735 & 46616 & 73835 \\
\hline Jul. Bugt, coastal & 19904 & 13023 & 30420 & 54550 & 38353 & 77589 \\
\hline Jul. Bugt, fjords & 27449 & - & - & 41204 & - & - \\
\hline Jul. Bugt, total & 47353 & 40472 & 57869 & 95754 & 79557 & 118793 \\
\hline \multicolumn{7}{|l|}{ King eider } \\
\hline St. Hellefiskebanke, $S<250$ & 48914 & 19132 & 125056 & & & \\
\hline St. Hellefiskebanke, $S \geq 250$ & 1058405 & 468443 & 2391371 & & & \\
\hline St. Hellefiskebanke, total & 1107318 & 506120 & 2422653 & NA & & \\
\hline \multicolumn{7}{|l|}{ Long-tailed duck } \\
\hline Nuuk, coastal & 13686 & 6042 & 30999 & 13332 & 7468 & 23445 \\
\hline Nuuk, fjords & 82 & & & & & \\
\hline Nuuk, total & 13768 & 6124 & 31081 & & & \\
\hline Jul. Bugt, coastal & 9909 & 5287 & 18574 & NA & & \\
\hline Jul. Bugt, fjords & 1303 & - & - & & & \\
\hline Jul. Bugt, total & 11212 & 6590 & 19877 & & & \\
\hline
\end{tabular}


on the bank and the fact that king eiders were relatively scarce outside the bank area (Supplementary Table S1).

\section{Common eider}

Common eider had the most wide-ranging distribution and accounted for as much as $52 \%$ of all observations. Among the total of 3604 sightings of common eider, $48 \%$ were recorded in the fjords, $51 \%$ in the coastal survey area and only $1 \%$ on the offshore bank (Table 1 ). In general, the eiders gathered in larger flocks in fjord systems (mean flock size 121.7) compared with the coastal survey area (mean flock size 10.7). A similar pattern was observed during the 1999 survey (Merkel et al. 2002).

As in 1999, common eider abundance in the coastal survey area was estimated with post-stratification according to flock size $(<10,10-100,>100)$ to overcome a large variation in flock size (Supplementary Table S1). The total abundance estimate for common eiders in the coastal survey area was 231651 birds (95\% CI: 194065$276517)$ in 2017, which was lower than the 1999 estimate (358960 birds; 95\% CI: 243 025-530202), although with overlapping CIs (Table 2). Proportionally, the CI was much smaller for the 2017 abundance estimate, primarily because of a much smaller variation in flock size amongst flocks $>100$ individuals. In contrast to the coastal survey area, the total count estimate for the fjords was roughly twice as high in 2017 compared to 1999 (211025 vs. 103834; Table 2). This difference can partly be explained by a larger effort in 2017, but not entirely. When compared as eiders per covered open-water fjord area, the density was still 42\% higher in 2017 (33.1 vs. 23.2 birds/ $\mathrm{km}^{2}$ ). Combined, the coastal area and the fjords sum up to approximately the same number of common eiders in south-west Greenland in the two survey years but with a much more precise estimate in 2017 (Table 2).

The coastal area and fjords around Nuuk $\left(\mathrm{ca} .64^{\circ} \mathrm{N}\right)$ and in Julianehåbsbugten in the south $\left(\mathrm{ca} .61^{\circ} \mathrm{N}\right)$ constituted important high-density wintering areas for the common eider in 2017, as they did in 1999 (Fig. 4, Table 3). A third and even more important area in 2017 was the Kangaatsiaq area $\left(\mathrm{ca} .68^{\circ} \mathrm{N}\right)$ in the north. On the basis of separate analyses, we estimated 137875 common eiders (95\% CI: $116511-174578$ ) in the Kangaatsiaq area, 86535 (95\% CI: 78281-102112) in the Nuuk area and 47353 (95\% CI: 40 472-57 869) in the Julianehåbsbugten area, the coastal survey and fjords combined. These abundance estimates indicate significantly more birds in the Nuuk area, but significantly fewer in Julianehåbsbugten in 2017 compared to 1999 (Table 3). The importance of the Kangaatsiaq area in 1999 is uncertain because of poor survey coverage of the fjords (but fast-ice cover was similar). In all three areas, most of the birds were located in the fjords in 2017 (Table 3).

\section{Long-tailed duck}

The winter population of long-tailed ducks in southwest Greenland was significantly smaller in 2017 (41 572 birds; 95\% CI: 31 396-55 241) compared to 1999 (94382 birds; 95\% CI: 66943-133070) (Table 2). However, the overall distribution of the birds was the same, with a continuous occurrence south of $65^{\circ} \mathrm{N}$ in the near-shore coastal waters and outermost regions of the fjords. North of $65^{\circ} \mathrm{N}$, long-tailed ducks gradually became less frequent (Fig. 5). Compared to most of the other species, overall density variation was rather small for the long-tailed duck and explains the rather narrow CI of the abundance estimate (Supplementary Table S1).

As in 1999, the Nuuk coastal survey area constituted an important high-density wintering area in 2017, with estimated 13686 (95\% CI: 6042-30999) long-tailed ducks (Table 3, Fig. 5). The Julianehåbsbugten area in the south $\left(\mathrm{ca} .61^{\circ} \mathrm{N}\right)$ also had densities above average in 2017, with estimated 11212 (95\% CI: 6590-19877) wintering long-tailed ducks (Table 3, Fig. 5).

\section{Thick-billed murre}

The thick-billed murre was rarely observed in southwest Greenland in 2017. Except for some observations between Maniitsoq and Nuuk, and a few from the Narsaq-Nanortalik area, the murres were nearly absent from the coastal survey area (Fig. 6). However, most of the murres were observed in the western part of the coastal area, indicating that their distribution continued further west in offshore areas. Only a single observation was made on Store Hellefiskebanke and no birds were seen in the fjords (Table 1).

The total abundance estimate for thick-billed murre in the coastal survey area was 1821 (95\% CI: 1014-3271) in 2017. In comparison, 125439 (95\% CI: 78 091-201497) wintering murres were estimated within the coastal survey area in 1999.

\section{Black guillemot}

The distribution of black guillemot in 2017 was confined to the coastal survey area north of Nuuk and Store Hellefiskebanke (Fig. 7). This is in contrast to 1999, when birds were dispersed throughout most of the coastal survey area (offshore banks not surveyed; Merkel et al. 2002). In both years, densities were highest in the dense pack ice north of $67^{\circ} \mathrm{N}$, and hardly any birds were observed in the fjords. The east-west distribution of the birds in 
the coastal survey area and on Store Hellefiskebanke indicates that their distribution continued further west in offshore areas (Fig. 7).

The abundance estimate for black guillemot in the coastal survey area was considerably lower in 2017 (4657 birds; 95\% CI: 2174-9973) compared to 1999 (Table 2; 12030 birds; 95\% CI: 5335-27 128), but the CIs overlap. Combined with the Store Hellefiskebanke estimate of 601 birds (95\% CI: 302-1196) and 16 birds observed in the fjords, the total abundance estimate for black guillemot in 2017 was 5274 birds (95\% CI: 2669-10437).

\section{Glaucous gull and Iceland gull}

The white gulls-glaucous gull and Iceland gull—were lumped together as they are difficult to tell apart from a fast-moving survey airplane. They were distributed throughout the coastal survey area and in the fjords. By number of sightings, the white gulls were the second most abundant "species." However, flock sizes were generally small, and $56 \%$ of the sightings were single-bird observations. In the coastal survey area, the white gulls were also widely distributed in the offshore western part, and it was clear that their distribution continued offshore, as was the case on Store Hellefiskebanke (Fig. 8). Highest densities occurred around Kangaatsiaq, Sisimiut, Maniitsoq and Nuuk.

The total abundance estimate for wintering white gulls within the survey area in 2017 was 76025 birds (95\% CI: 45 744-136 085), including 2734 birds (95\% CI: 678-1 1033 ) on Store Hellefiskebanke and a minimum of 10522 birds in the fjords (Table 2). White gulls were not recorded in 1999.

\section{Great black-backed gull}

Great black-backed gulls were widely distributed throughout the coastal survey area and in the fjords (Fig. 9). Most sightings were single bird observations, $91 \%$ in the coastal survey area and $63 \%$ in the fjords. Very few birds were seen on the offshore bank transects, and only within or close to the coastal survey area. However, at least in some areas of the coastal area, the great blackbacked gulls were widely distributed into the west, indicating that the survey probably did not cover the entire winter distribution area of this species. High-density areas were not as easily identified as for the white gulls, but at least the Kangaatsiaq area appeared to be one (Fig. 9).

The total abundance estimate for wintering great black-backed gull within the survey area in 2017 was 6111 birds (95\% CI: 4895-7673), including a minimum of 620 birds in the fjords (Table 2). Great black-backed gulls were not recorded in 1999.

\section{Mallard}

Mallards were observed throughout the coastal survey area, but strictly confined to the coastline and scarce or absent in several regions. When common in the coastal area, they were usually also frequently observed in the adjacent fjords (Fig. 10, Table 1). Important high-density wintering areas for the mallard in 2017 were the same as for common eider, namely the coastal area and fjords around Kangaatsiaq (ca. $\left.68^{\circ} \mathrm{N}\right)$, around Nuuk $\left(\mathrm{ca} .64^{\circ} \mathrm{N}\right)$ and in Julianehåbsbugten (ca. $61^{\circ} \mathrm{N}$, Fig. 10). In addition, the area around $63^{\circ} \mathrm{N}$ (south of Nuuk) also seems quite important for the mallard.

The total abundance estimate for wintering mallards in south-west Greenland in 2017 was 7606 birds (95\% CI: 4701-13442), including a minimum of 1821 birds in the fjords (Table 2). Distance sampling analyses were not applied to mallards in the coastal survey area in 1999. However, it is striking that no birds were observed north of ca. $65^{\circ} \mathrm{N}$ in the coastal survey area in 1999 (Merkel et al. 2002). In the fjords, mallards were not recorded in 1999.

\section{Red-breasted merganser}

The distribution of red-breasted merganser resembled the mallard, both in terms of the frequency of sightings and the important high-density areas (Fig. 11, Table 1). Red-breasted merganser was also strictly confined to the coastline. However, flock sizes were smaller than for the mallard, resulting in a smaller winter population estimate for the red-breasted merganser. The total abundance estimate for south-west Greenland was 3199 birds (95\% CI: 2266-5087), including a minimum of 1356 birds in the fjords (Table 2). In 1999, abundance of red-breasted merganser in the coastal survey area was not estimated but, like the mallards, they appeared to be scarce or absent north of Nuuk (Merkel et al. 2002). In the fjords, red-breasted mergansers were not consistently recorded in 1999.

\section{Great cormorant}

Great cormorants were observed throughout the coastal survey area, although scarce in some regions (Fig. 12). The largest region of absence was from around Maniitsoq and north to around Sisimiut (ca. $65-67^{\circ} \mathrm{N}$ ). Highest densities were detected in the coastal survey area and fjords of the Kangaatsiaq area $\left(\mathrm{ca} .68^{\circ} \mathrm{N}\right)$, the coastal area around Nuuk $\left(\mathrm{ca} .64^{\circ} \mathrm{N}\right)$ and the outer range of the fjords in the northern part of Julianehåbsbugten (ca. $61^{\circ} \mathrm{N}$, Fig. 12). Cormorants were not common in the fjords, except for the two areas just mentioned.

The total abundance estimate for wintering great cormorants in south-west Greenland in 2017 was 7701 birds (95\% CI: 4025-15077), with the vast majority (95\%) in 
the coastal survey area (Table 2). Abundance of great cormorant was not estimated in 1999, but the overall distribution pattern was the same (Merkel et al. 2002).

\section{Other species}

Northern fulmar (Fulmaris glacialis). A single observation was made of this species in 2017 , about $110 \mathrm{~km}$ south of Nuuk $\left(63.1^{\circ} \mathrm{N}\right)$, in the western part of the coastal survey area. This is in stark contrast to 1999, when birds were frequently observed between $62^{\circ}$ and $66^{\circ} \mathrm{N}$ and around the southern tip of Greenland (82 sightings, 1153 individuals, Merkel et al. 2002).

Harlequin duck (Histrionicus histrionicus). Four sightings (nine individuals) were made during the 2017 survey. Three were in the coastal survey area next to Nuuk, and one observation was in the Kangaatsiaq fjord system $\left(68.2^{\circ} \mathrm{N}\right)$. Harlequin ducks were also scarcely observed in 1999 , and probably most individuals of this species were overlooked during both surveys, partly because of their small size, but mainly because they dive when disturbed and prefer the tidal zone and, when resting, land.

Black-legged kittiwake (Rissa tridactyla). Only a single observation of this species was made in 2017, close to Maniitsoq $\left(65.3^{\circ} \mathrm{N}\right)$. This is very different than the 1999 survey, when birds were observed on a regular basis between $62^{\circ}$ and $66^{\circ} \mathrm{N}$ (47 sightings, 3232 individuals), and in high densities in the fjord system around Maniitsoq (Merkel et al. 2002).

White-tailed eagle (Haliaeetus albicilla). In total, 43 eagles were observed in south-west Greenland in 2017 (Table 1). Especially in the fjords, the frequency of sightings was high compared to 1999 (Merkel et al. 2002). Key wintering areas in south-west Greenland in 2017 appear to have been the fjord system of Nuuk, the coastal area and fjords between $62^{\circ}$ and $63^{\circ} \mathrm{N}$, and the fjords in Julianehåbsbugten.

Little auk (Alle alle). This species was not observed, but its small size makes it likely that scattered occurrences were overlooked. However, its main winter distribution is known to be offshore in the Davis Strait (Fort et al. 2013).

Raven (Corvus corax). Ravens occurred throughout the survey area but were not recorded.

\section{Discussion}

\section{Main results and key wintering sites}

The most important findings of this study are the results for common eider, king eider, long-tailed duck, great cormorant, mallard and red-breasted merganser. For these species, we present updated or entirely new information on their distribution and abundance in the internationally important wintering area of south-west Greenland. They were all widespread and often numerous in shallow water areas, or in close proximity to such areas, that is, the coastal survey area, the fjords and the offshore bank, Store Hellefiskebanke. These nine species combined constitute a minimum of 1.7 million birds and reinforce the importance of south-west Greenland as a wintering area for seabirds (for an overview, see Boertmann et al. 2006). The area is especially important for the king eider and the common eider, which alone account for a minimum of 1.5 million birds. For all species but the king eider and the long-tailed duck, the numbers shown in Table 2 represent minimum estimates of the winter population because not all fjords were surveyed and, in the case of gulls and alcids, also because of an expected additional pelagic distribution (Mosbech \& Johnson 1999). For the king eider and long-tailed duck, the survey effort in 2017 probably covered the entire wintering range in south-west Greenland (see below), and the abundance estimates for these species are therefore considered relatively complete.

As in 1999 (Merkel et al. 2002), the coastal survey area and the adjoining fjord systems around Nuuk and Julianehåbsbugten were confirmed as key wintering sites for several species in 2017, namely common eider, longtailed duck (only coastal), glaucous/Iceland gull (only Nuuk), mallard, red-breasted merganser and great cormorant (only coastal). For the same species, except the long-tailed duck, the Kangaatsiaq area in the north was also a key wintering site in 2017.

The importance of Store Hellefiskebanke for wintering king eiders, originating from breeding grounds in the Canadian Arctic (Lyngs 2003; Mosbech, Danø et al. 2006), was also clearly demonstrated. The current abundance estimate suggests a wintering population of around 1.1 million king eiders on Store Hellefiskebanke, which seems to be higher than earlier estimates. On the basis of observations from marine mammal surveys in March 1981, 1982, 1991 and 1993, Mosbech \& Johnson (1999) estimated about 300000 king eiders wintering in the area in March (maximum year estimate 437000 ). On the basis of a ship-based survey in November 2003, Mosbech et al. (2007) estimated about 750000 king eiders (75\% CI: 529000-1083000) and Frederiksen et al. (2008) estimated about 400000 birds (75\% CI: 227000-709000) from an aerial survey in late April/early May 2006. The relative importance of Store Hellefiskebanke has also been confirmed in a tracking study of king eider winter habitats in west Greenland (Mosbech, Danø et al. 2006). Previously, the offshore bank Fyllas Banke west of Nuuk has also been identified as an important wintering area for the king eider (Mosbech \& Johnson 1999), and Fyllas Banke cannot be ruled out as an additional wintering 
site in 2017, as it was not covered during the survey. However, there is some indication that Fyllas Banke is mainly used at times when very dense pack ice or new ice forming in calm freezing weather closes the open water at Store Hellefiskebanke, forcing the birds to seek alternative winter habitats in south-west Greenland (Mosbech, Danø et al. 2006; Merkel et al. 2012).

The thick-billed murre, northern fulmar and blacklegged kittiwake were all scarcely observed within the survey area in 2017 and much less so than during the 1999 survey (Merkel et al. 2002). The reason for this is unknown (but see below). However, it is known from other studies that these species are distributed throughout Davis Strait in offshore waters (Durinck \& Falk 1996; Heide-Jørgensen et al. 1999; Mosbech \& Johnson 1999; Frederiksen et al. 2012; Frederiksen et al. 2016). Thus, the survey adds little to our knowledge about the winter population size of these species but does add information about the magnitude of fluctuations within their marginal distribution range along the coast. Black guillemot was more common within the survey area, but its distribution probably also continued west in the pack ice of Davis Strait (Mosbech \& Johnson 1999).

\section{First available abundance estimates}

This study has produced the first winter abundance estimates for glaucous gull/Iceland gull, great black-backed gull, great cormorant, mallard and red-breasted merganser, representing the entire coastal area of southwest Greenland and $56 \%$ of the open water in adjoining fjords. For the reasons already mentioned, the estimates are conservative, but they still add valuable information about the magnitude of the wintering populations (Table 2).

Great cormorant, mallard and red-breasted merganser all constitute discrete Greenlandic populations and the mallard (Anas platyrhynchos conboschas) an endemic subspecies (Boertmann 2007). All three species were confined to the coastal area and the fjords, but the totals are all rather small compared to previous expectations based on crude estimates or educated guesses: 20000 great cormorants, <50000 mallards and <20000 red-breasted mergansers (Boertmann et al. 2004; Boertmann 2006). An extrapolation of the observed fjord densities to the remaining 44\% uncovered open-water fjord areas adds relatively little to the totals (around 300 great cormorants, 1400 mallards and 1100 red-breasted mergansers). Either previous expectations were too high or the current survey greatly underestimated the winter populations. Our fjord surveys were primarily designed to detect larger aggregations of common eiders. Mallards and red-breasted mergansers were often seen much closer to the coastline and in smaller flocks, making them both more difficult to detect. Cormorants in fjords were often recorded resting on cliffs and only detected because they were disturbed. Cormorants could therefore easily have been overlooked in some fjords, and for all three species, it must be emphasized that our total estimates represent an absolute minimum.

Extrapolation of the estimated gull numbers to a total winter abundance is not possible as these birds are also expected to have a pelagic distribution (Mosbech \& Johnson 1999). The combined coastal area-fjord estimate for glaucous gull/Iceland gull of around 76000 birds therefore represents an unknown proportion of the total winter population in south-west Greenland. We expect the total to be higher, but migration patterns of gulls breeding in Greenland and Canada are not well studied (Boertmann et al. 2006). For great black-backed gull, Boertmann et al. (2006) expected a winter population of around 22000 birds in south-west Greenland on the basis of information about the breeding population in Greenland. We found only around a third of this number within the coastal area and the fjords (Table 2). All three gull species were found in high numbers in areas with human settlement/ activities, but the survey did not include total counts in such areas. The total estimates we report therefore also represent an absolute minimum.

\section{Apparent changes in distribution and abundance}

For king eider, common eider, long-tailed duck, thickbilled murre and black guillemot, the abundance estimate for the coastal survey area was considerably lower in 2017 than in 1999, although not significantly so for the common eider and black guillemot (Table 2).

Both king eider and black guillemot were largely missing from the coastal survey area south of Nuuk in 2017. However, the fact that only part of the potential distribution range was covered in one or both years, combined with the knowledge that the winter distribution of both species can fluctuate according to the ice situation (Durinck \& Falk 1996; Mosbech \& Johnson 1999; Mosbech, Danø et al. 2006), makes it too uncertain to link the observed changes in numbers to any real changes in population sizes.

For the thick-billed murre, the difference in abundance in the coastal survey area between 1999 and 2017 is even more striking. Again, the large difference may be caused by a geographical shift within the total winter distribution range, of which we covered only a minor part in both years, or it may be a result of a true population decline. In this case, the large decline in the coastal survey area does indeed coincide with evidence of a significant decline among the breeding populations in Greenland, 
Iceland and Svalbard, which all contribute to the winter population in south-west Greenland (Descamps et al. 2013; Merkel et al. 2014). Our lack of observations is also in line with local knowledge from hunters, which state that they more often than in the past need to travel far offshore to shoot murres (Haastrup 2017).

In west and north-west Greenland, the breeding population of common eider has increased substantially between the two winter surveys (Merkel 2010). On the basis of this increase, we could have expected an increase of the winter population in south-west Greenland. However, a much larger contributor to the winter population in south-west Greenland is the east Canadian breeding population (Lyngs 2003; Mosbech, Gilchrist et al. 2006), and the trend of this breeding population is less clear. An increase in the breeding population has been observed within the Canadian High Arctic (Maftei et al. 2015), but the same may not be the case further south on account of local effects of avian cholera and the greater influence of polar bear (Ursus maritimus) predation (Descamps et al. 2012; Iverson et al. 2014). Further, the flyway of the east Canadian breeding population splits between two main wintering sites, south-west Greenland and Newfoundland (Mosbech, Gilchrist et al. 2006), and it is unknown if the proportional use of these two wintering sites has changed. At this point, it is therefore uncertain if the combined breeding population of west Greenland and east Canada has increased or not. If the fjord densities observed in 1999 and 2017 are extrapolated to the remaining uncovered open-water areas in the fjords and combined with the abundance estimates for the coastal survey area, this results in a total winter population size of around 602500 birds in 1999 and 606000 birds in 2017. The 2017 winter survey thus suggests an overall unchanged winter population size since 1999.

The distribution of long-tailed ducks was almost entirely confined to near-shore coastal waters and the outermost regions of the fjords both in the current survey (Fig. 5) and in 1999 (Merkel et al. 2002). Except for rare observations during a single survey (Heide-Jørgensen et al. 1999), no previous surveys have reported long-tailed ducks west of the coastal survey area (Durinck $\delta$ Falk 1996; Mosbech \& Johnson 1999). The large decline in abundance of long-tailed ducks in the coastal survey area from 1999 to 2017 therefore probably represents a real decline in the size of the winter population. However, the origins of the wintering birds in south-west Greenland are to some extent unknown. Ringing recoveries and tracking studies demonstrate that parts of the breeding populations in Greenland and Iceland are contributing (Lyngs 2003; Mosbech et al. 2011). Both of these breeding populations are rather small (Asbirk et al. 1997; Boertmann 2007) and probably can explain only minor abundance changes in the wintering area. At this point, the contribution from the larger breeding population in Canada is unclear, but here the breeding numbers seem to be declining (Lyngs 2003; SDJV 2018; M. Mallory, unpubl. data).

The fact that the black-legged kittiwake was completely missing during the 2017 survey also coincides with a general decline among breeding populations in the North Atlantic (Descamps et al. 2017). However, as with the alcids and the other gulls, only a small portion of the total winter range was covered during both surveys, so the difference may be due to geographical shifts within the overall wintering area.

The apparently more frequent observations of whitetailed eagles in 2017 should not be an object of interpretation as this species was not systematically recorded in the fjords in 1999.

\section{Concerns and recommendations}

Seabirds are known as highly vulnerable to oil pollution (Mosbech et al. 1996), and oil exploitation off west Greenland has been recognized as a potential future threat to the large number of wintering seabirds in south-west Greenland (Merkel et al. 2002). However, today only few companies are active in west Greenland, so the interest in pursuing this resource appears to have subsided (Wegeberg et al. 2018). Future risks of oil contamination of seabirds in west Greenland now relate to the expectations of a general increase in shipping activity due to reduced ice cover in the High Arctic (PAME 2009; Christensen et al. 2018). The threat from hunting (see Merkel et al. 2002) is also dropping as a result of a large reduction in seabird harvests in Greenland from 2002 and onwards as hunting regulations and hunting engagement have changed (Merkel \& Christensen 2008). For the common eider, this is believed to be the main reason for the observed increase in the breeding population in north-west Greenland (Merkel 2010; Burnham et al. 2012). For the thick-billed murre, hunting is still a conservation concern. Despite a reduction to approximately one-third of previous hunting levels, there are still no signs of recovery among breeding populations of this species (Descamps et al. 2013; Merkel et al. 2014).

An alarming result from this study is the fact that all species with abundance estimates available from 1999 (king eider, common eider, long-tailed duck, thick-billed murre and black guillemot) appeared to be much less abundant in the coastal survey area in 2017. Together, these five key species totalled some 740000 birds in the coastal survey area in 1999, whereas the corresponding figure for 2017 was approximately 300000 birds-a reduction of $60 \%$. As already mentioned, this may partly be a result of annual 
fluctuations in distribution patterns or other changes that we do not know about (e.g., a shift in migration patterns), but we also need to be open to the possibility that the coastal habitats are changing, biologically, physically or otherwise, in a way that makes them less attractive for seabirds. We recommend that this is addressed in future studies and monitoring protocols. Among species with a dominant pelagic winter distribution, physical changes in the marine environment south of Greenland have already been linked to population declines in thick-billed murres in Svalbard (Descamps et al. 2013; Fluhr et al. 2017).

Another important point demanding attention now and in the future is the impact of climate change on the size of the open-water area in south-west Greenland and the winter range of the seabirds. A few decades ago, the northern limit of the open-water area was normally around Sisimiut, at $67^{\circ} \mathrm{N}$ (Valeur et al. 1996), whereas today it often extends as far north as Disko Bay, at $70^{\circ} \mathrm{N}$. Even as far north as Upernavik, at $73^{\circ} \mathrm{N}$, an important breeding area for common eider, local hunters/fishermen now reports open water and the presence of eiders in the polar night until midwinter. The fate of these eiders after midwinter is unknown, but on several occasions the locals noted that the eiders were in a poor body condition around midwinter, so staying in the Upernavik region throughout the winter is probably not an option at this point. However, this may change in the near future, with possible implications for the distribution and abundance of eiders within the traditional wintering area in south-west Greenland. It is also worth noting that in the survey reported here, both mallards and red-breasted mergansers were observed as far north as Kangaatsiaq, whereas in 1999 the northernmost observations were around Nuuk. Also in contrast to 1999, king eiders were hardly seen south of Nuuk in 2017, and black guillemots were completely absent along the southern portion of the coast. At this point, it is premature to conclude whether these are cases of a northern range shift or just annual fluctuations, but it is important to address this in future studies.

The number of surveys so far conducted in southwest Greenland on wintering seabirds is clearly insufficient. There is a need to increase their frequency to better understand year-to-year variation in winter distribution and abundance. Ideally, the surveys should include all the offshore shallow banks, for example, Fyllas Banke, since this would result in full coverage of the king eider distribution range and make interpretation of this species much easier. It has to be acknowledged, however, that the windy conditions that typically characterize the offshore ice-free waters of south-west Greenland make this a challenging task. It is also recommended to extend the survey to include all the fjords, to the benefit of several species. Weather-wise, this is more achievable but will require two or three full days of additional survey effort.
Finally, it is worth stressing that detailed tracking studies of individual birds are an important complementary tool to aerial surveys of distribution and abundance. Especially for the larger seaducks, such as king and common eider, Argos-based satellite telemetry is a useful and well-tested technique (Fast et al. 2011) that can provide detailed information on migration patterns as well as daily, weekly or monthly movement patterns within the wintering area. Such work has already been carried out for shared populations of king and common eiders in Greenland and Canada (Merkel et al. 2006; Mosbech, Danø et al. 2006; Mosbech, Gilchrist et al. 2006), but the studies are now more than 15 years old and there is a need to explore if movements have changed significantly in the meantime. An additional future source of complementary information may be emerging techniques using biological markers and next-generation DNA sequencing to directly assign harvested birds to source colonies or, as in the case of Steenweg et al. (2017), assign breeding birds to source wintering areas.

\section{Acknowledgements}

We would like to thank Friðrik Adólfsson (Norlandair, Akureyri, Iceland) for a smooth process with the survey contract and the pilots Kristinn Elvar Gunnarsson, Jonas Finnbogason, Guðmundur Emilsson and Stefán Árnason. We are also grateful to David Boertmann for providing valuable comments to an earlier version of this article. We would also like to thank the two reviewers, Claude R. Joiris and Sveinn Are Hanssen, whose comments and suggestions have significantly improved the article. Observers during the survey were Rasmus Due Nielsen, Flemming Ravn Merkel, Ib Krag Petersen and Jacob Sterup.

\section{Disclosure statement}

The authors report no conflict of interest.

\section{Funding}

This study was part of the Environmental Oil Study Program 2015-2017 (Project 0009) conducted by the Danish Centre for Environment and Energy, Aarhus University, and the Greenland Institute of Natural Resources. The programme was carried out on behalf of the Environmental Agency for Mineral Resource Activities, Greenland Government, and was financed through the Mineral Licence and Safety Authority, Greenland Government, by hydrocarbon licence holders in the area. 


\section{References}

Asbirk S., Berg L., Hardeng G., Koskimies P. \& Petersen A. 1997. Population sizes and trends of birds in the Nordic countries 1978-1994. TemaNord Report 1997:614. Copenhagen: Nordic Council of Ministers.

Boertmann D. 2006. Optxllinger af ridekolonier i Disko Bugt, Arfersiorfik Fjord og Nordre Strømfjord i 2005. (Censuses of kittiwake colonies in Disko Bay, Arfersiorfik Fjord and Nordre Strømfjord in 2005.) NERI Technical Report 225. Aarhus: National Environmental Research Institute, Aarhus University.

Boertmann D. 2007. Grønlands Rødliste 2007. (Greenland's Red List 2007.) Roskilde: National Environmental Research Institute of Denmark, Aarhus University/Directorate for Environment and Nature, Greenland Home Rule.

Boertmann D., Lyngs P., Merkel F.R. \& Mosbech A. 2004. The significance of SW Greenland as winter quarters for seabirds. Bird Conservation International 14, 87-112, doi: 10.1017/S0959270904000127.

Boertmann D., Mosbech A. \& Merkel F.R. 2006. The importance of southwest Greenland for wintering seabirds. British Birds 99, 282-298, doi: 10.1017/S0959270904000127.

Buckland S.T., Anderson D.R., Burnham K.P., Laake J.L., Borchers D.L. \& Thomas L. 2001. Introduction to distance sampling. Estimating abundance of biological populations. Oxford: Oxford University Press.

Buckland S.T., Anderson D.R., Burnham K.P., Laake J.L., Borchers D.L. \& Thomas L. 2004. Advanced distance sampling. Estimating abundance of biological populations. Oxford: Oxford University Press.

Buckland S.T., Anderson D.R. \& Laake J.L. 1993. Distance sampling. New York: Chapman \& Hall.

Burnham K.K., Johnson J.A., Konkel B. \& Burnham J. 2012. Nesting common eider (Somateria mollissima) population quintuples in northwest Greenland. Arctic 65, 456-464, doi: 10.14430/arctic4243.

Cairns D.K. 1987. Seabirds as indicators of marine food supplies. Biological Oceanography 5, 261-271, doi: 10.1080/01965581.1987.10749517.

Christensen T., Lasserre F., Dawson J., Guy E. \& Pelletier J.F. 2018. Shipping. In A. Mosbech et al. (eds.): Adaptation actions for a changing Arctic: perspectives from the Baffin Bay/ Davis Strait region. Pp. 243-260. Oslo: Arctic Monitoring and Assessment Programme.

Descamps S., Anker-Nilssen T., Barrett R.T., Irons D.B., Merkel F., Robertson G.J., Yoccoz N.G., Mallory M.L., Montevecchi W.A., Boertmann D., Artukhin Y., Christensen-Dalsgaard S., Erikstad K.E., Gilchrist H.G., Labansen A.L., Lorentsen S.H., Mosbech A., Olsen B., Petersen A., Rail J.F., Renner H.M., Strom H., Systad G.H., Wilhelm S.I. \& Zelenskaya L. 2017. Circumpolar dynamics of a marine top-predator track ocean warming rates. Global Change Biology 23, 3770-3780, doi: 10.1111/gcb.13715.

Descamps S., Jenouvrier S., Gilchrist H.G. \& Forbes M.R. 2012. Avian cholera, a threat to the viability of an Arctic seabird colony? PLoS One 7, e29659, doi: 10.1371/journal. pone.0029659.

Descamps S., Strøm H. \& Steen H. 2013. Decline of an Arctic top predator: synchrony in colony size fluctuations, risk of extinction and the subpolar gyre. Oecologia 173, 12711282, doi: 10.1007/s00442-013-2701-0.

Durinck J. \& Falk K. 1996. The distribution and abundance of seabirds off southwestern Greenland in autumn and winter 1988-1989. Polar Research 15, 23-42, doi: 10.3402/ polar.v15il.6634.

Fast P.L.F., Fast M., Mosbech A., Sonne C., Gilchrist H.G. \& Descamps S. 2011. Effects of implanted satellite transmitters on behavior and survival of female common eiders. Journal of Wildlife Management 75, 1553-1557, doi: 10.1002/Jwmg.220.

Fluhr J., Strøm H., Pradel R., Duriez O., Beaugrand G. \& Descamps S. 2017. Weakening of the subpolar gyre as a key driver of North Atlantic seabird demography: a case study with Brünnich's guillemots in Svalbard. Marine Ecology Progress Series 563, 1-1 1, doi: 10.3354/meps 11982.

Fort J., Moe B., Strom H., Gremillet D., Welcker J., Schultner J., Jerstad K., Johansen K.L., Phillips R.A. \& Mosbech A. 2013. Multicolony tracking reveals potential threats to little auks wintering in the North Atlantic from marine pollution and shrinking sea ice cover. Diversity and Distributions 19, 1322-1332, doi: 10.1111/ddi.12105.

Frederiksen M. 2010. Appendix 1: seabirds in the North East Atlantic. A review of status, trends and anthropogenic impact. Action plan for seabirds in western-Nordic areas. Pp. 47-122. Copenhagen: Nordic Council of Ministers.

Frederiksen M. 2017. Synthesis: status and trends of Arctic marine biodiversity and monitoring. In T. Barry et al. (eds.): State of the Arctic marine biodiversity report. Pp. 175194. Akureyri, Iceland: Conservation of Arctic Flora and Fauna International Secretariat.

Frederiksen M., Anker-Nilssen T., Beaugrand G. \& Wanless S. 2013. Climate, copepods and seabirds in the boreal Northeast Atlantic-current state and future outlook. Global Change Biology 19, 364-372, doi: 10.1111/gcb.12072.

Frederiksen M., Boertmann D., Cuykens A.B., Hansen J., Jespersen M., Johansen K.L., Mosbech A., Nielsen T.G. \& Söderkvist J. 2008. Life in the marginal ice zone: oceanographic and biological surveys in Disko Bay and south-eastern Baffin Bay April-May 2006. NERI Technical Report 694. Roskilde: National Environmental Research Institute of Denmark, Aarhus University.

Frederiksen M., Descamps S., Erikstad K.E., Gaston A.J., Gilchrist H.G., Grémillet D., Johansen K., Kolbeinsson Y., Linnebjerg J.F., Mallory M., McFarlane Tranquilla A.M., Merkel F., Montevecchi W.A., Mosbech A., Reiertsen T.K., Robertson G., Steen H., Strøm H. \& Thórarinsson T.L. 2016. Migration and wintering of a declining seabird, the thick-billed murre Uria lomvia, on an ocean basin scale: conservation implications. Biological Conservation 200, 26-35, doi: 10.1016/j.biocon.2016.05.011.

Frederiksen M., Moe B., Daunt F., Phillips R.A., Barrett R.T., Bogdanova M.I., Boulinier T., Chardine J.W., Chastel O., Chivers L.S., Christensen-Dalsgaard S., Clement-Chastel C., Colhoun K., Freeman R., Gaston A.J., Gonzalez-Solis J., Goutte A., Gremillet D., Guilford T., Jensen G.H., Krasnov Y., Lorentsen S.H., Mallory M.L., Newell M., Olsen B., Shaw D., Steen H., Strom H., Systad G.H., Thorarinsson T.L. \& Anker-Nilssen T. 2012. Multicolony tracking reveals 
the winter distribution of a pelagic seabird on an ocean basin scale. Diversity and Distributions 18, 530-542, doi: $10.1111 /$ j.1472-4642.2011.00864.x.

Ganter B. \& Gaston A.J. 2013. Birds. In H. Meltofte (ed.): Arctic biodiversity assessment. Status and trends in Arctic biodiversity. Pp. 142-180. Akureyri, Iceland: Conservation of Arctic Flora and Fauna International Secretariat.

Gonzalez-Bergonzoni I., Johansen K.L., Mosbech A., Landkildehus F., Jeppesen E. \& Davidson T.A. 2017. Small birds, big effects: the little auk (Alle alle) transforms High Arctic ecosystems. Proceedings of the Royal Society B 284, article no. 20162572, doi: 10.1098/rspb.2016.2572.

Green J.G. \& Elmberg J. 2014. Ecosystem services provided by waterbirds. Biological Reviews 89, 105-122, doi: 10.1111/ brv.12045.

Guillemette M., Himmelman J.H., Barette C. \& Reed A. 1993. Habitat selection by common eiders in winter and its interaction with flock size. Canadian Journal of Zoology 71, 1259-1266, doi: 10.1139/z93-172.

Haastrup A. 2017. Appaqanngila?-Ingen lomvie? En analyse af forskellige former for viden om lomvien og bxredygtighedstanker $i$ Gronland. (No murres? An analysis of various types of knowledge about murres and thoughts about sustainability in Greenland.) Master's degree, Dept of Anthropology, University of Copenhagen.

Heide-Jørgensen M.P., Acquarone M. \& Merkel F.R. 1999. Flytxllinger af fugle og havpattedyr $i$ Vestgronland 1998. (Aerial counts of birds and marine mammals in western Greenland, 1998.) Nuuk: Greenland Institute of Natural Resources.

Huntington H.P., Anisimova O., Christensen T., Fenge T., Hoel A.H., Jung T., Klokov K., Merkel F.R., Mustonen K., Mustonen T., Sejersen F., Snyder J., Stonehouse B. \& Trainor S.F. 2013. Provisioning and cultural services. In H. Meltofte (ed.): Arctic biodiversity assessment. Status and trends in Arctic biodiversity. Pp. 593-626. Akureyri, Iceland: Conservation of Arctic Flora and Fauna International Secretariat.

Irons D., Petersen A., Anker-Nilssen T., Artukhin Y., Barrett R., Boertmann D., Gavrilo M., Gilchrist H.G., Hansen E.S., Hario M., Kuletz K.J., Mallory M.L., Merkel F.R., Mosbech A., Labansen A.L., Olsen B., Österblom H., Reid J., Robertson G., Rönkä M. \& Strøm H. 2015. Circumpolar Seabird Monitoring Plan. CAFF Monitoring Report 17. Akureyri, Iceland: Conservation of Arctic Flora and Fauna International Secretariat.

Irons D.B., Anker-Nilssen T., Gaston A.J., Byrd G.V., Falk K., Gilchrist H.G., Hario M., Hjernquist M., Krasnov Y.V., Mosbech A., Olsen B., Petersen A., Reid J.B., Robertson G.J., Strom H. \& Wohl K.D. 2008. Fluctuations in circumpolar seabird populations linked to climate oscillations. Global Change Biology 14, 1455-1463, doi: 10.1111/j.1365-2486.2008.01581.x.

Iverson S., Gilchrist H.G., Smith P.A., Gaston A.J. \& Forbes M.R. 2014. Longer ice-free seasons increase the risk of nest depredation by polar bears for colonial breeding birds in the Canadian Arctic. Proceedings of the Royal Society B 281, article no. 20133128, doi: 10.1098/rspb.2013.3128.

Kuletz K.J., Mallory M.L., Gilchrist H.G., Robertson G., Merkel F.R., Olsen B., Hansen E.S., Rönkä M., Anker-Nilssen T., Strøm H., Descamps S., Gavrilo M., Kaler R., Irons
D. \& Below A. 2017. Seabirds. In T. Barry et al. (eds.): State of the Arctic marine biodiversity report. Pp. 129-147. Akureyri, Iceland: Conservation of Arctic Flora and Fauna International Secretariat.

Lyngs P. 2003. Migration and winter ranges of birds in Greenland-an analysis of ringing recoveries. Dansk Ornitologisk Forenings Tidsskrift 97, 1-167.

Maftei M., Davis S.E. \& Mallory M.L. 2015. Assessing regional populations of ground-nesting marine birds in the Canadian High Arctic. Polar Research 34, article no. 25055 , doi: 10.3402/polar.v34.25055.

Merkel F., Boertmann D., Mosbech A. \& Ugarte F. 2012. The Davis Strait. A preliminary strategic environmental impact assessment of hydrocarbon activities in the eastern Davis Strait. Scientific Report from DCE 15. Roskilde: Danish Centre for Environment and Energy, Aarhus University.

Merkel F., Labansen A.L., Boertmann D., Mosbech A., Egevang C., Falk K., Linnebjerg J.F., Frederiksen M. \& Kampp K. 2014. Declining trends in the majority of Greenland's thickbilled murre (Uria lomvia) colonies 1981-2011. Polar Biology 37, 1061-1071, doi: 10.1007/s00300-014-1500-3.

Merkel F.R. 2010. Evidence of recent population recovery in common eiders breeding in western Greenland. Journal of Wildlife Management 74, 1869-1874, doi: 10.2193/2009-189.

Merkel F.R. \& Barry T. 2008. Seabird harvest in the Arctic. CAFF Technical Report 16. Akureyri, Iceland: Circumpolar Seabird Working Group, Conservation of Arctic Flora and Fauna.

Merkel F.R. \& Christensen T. 2008. Seabird harvest in Greenland. In F.R. Merkel \& T. Barry (eds.): Seabird harvest in the Arctic. Pp. 41-49. Akureyri, Iceland: Circumpolar Seabird Working Group, Conservation of Arctic Flora and Fauna.

Merkel F.R., Franke A., Ugarte F., Statham S., Ferguson S., Wenzel G., Hotson C., Gauthier G., Lee D. \& Berteaux A. 2018. Hunting. In A. Mosbech et al. (eds.): Adaptation actions for a changing Arctic: perspectives from the Baffin Bay/ Davis Strait region. Pp. 177-194. Oslo: Arctic Monitoring and Assessment Programme.

Merkel F.R. \& Mosbech A. 2008. Diurnal and nocturnal feeding strategies in common eiders. Waterbirds 31, 580-586, doi: 10.1675/1524-4695-31.4.580.

Merkel F.R., Mosbech A., Boertmann D. \& Grøndahl L. 2002. Winter seabird distribution and abundance off south-western Greenland, 1999. Polar Research 21, 17-36, doi: 10.1111/j.1751-8369.2002.tb00064.x.

Merkel F.R., Mosbech A., Sonne C., Flagstad A., Falk K. \& Jamieson S.E. 2006. Local movements, home ranges and body condition of common eiders Somateria mollissima wintering in Greenland. Ardea 94, 639-650.

Mosbech A., Boertmann D. \& Jespersen M. 2007. Strategic environmental impact assessment of hydrocarbon activities in the Disko West area. NERI Technical Report 618. Roskilde: National Environmental Research Institute of Denmark, Aarhus University. Mosbech A., Danø R., Merkel F.R., Sonne C., Gilchrist H.G. \& Flagstad A. 2006. Use of satellite telemetry to locate key habitats for king eiders Somateria spectabilis in west Greenland. In G.C. Boere et al. (eds.): Waterbirds around the world. Pp. 769-776. Edinburgh: TSO Scotland Ltd. 
Mosbech A., Dietz R., Boertmann D. \& Johansen P. 1996. Oil exploration in the Fylla area. An initial assessment of potential environmental impacts. NERI Technical Report 156. Roskilde: National Environmental Research Institute of Denmark, Aarhus University.

Mosbech A., Gilchrist H.G., Merkel F.R., Sonne C., Flagstad A. \& Nyegaard H. 2006. Year-round movements of northern common eiders Somateria mollissima borealis breeding in Arctic Canada and west Greenland followed by satellite telemetry. Ardea 94, 651-665.

Mosbech A., Johansen K., Bjerrum M. \& Sonne C. 2011. Satellite tracking of long-tailed ducks from Myggbukta. In D. Boertmann \& A. Mosbech (eds.): The western Greenland Sea, a strategic environmental impact assessment of hydrocarbon activities. Scientific Report 22. Pp. 98-99. Roskilde: Danish Centre for Environment and Energy, Aarhus University.

Mosbech A. \& Johnson S.R. 1999. Late winter distribution and abundance of sea-associated birds in south-western Greenland, the Davis Strait and southern Baffin Bay. Polar Research 18, 1-17, doi: 10.1111/j.1751-8369.1999. tb00273.x.

PAME 2009. Arctic Marine Shipping Assessment 2009 Report. Akureyri, Iceland: Protection of the Arctic Marine Environment Working Group, Arctic Council.

Parsons M., Mitchell I., Butler A., Ratcliffe N., Frederiksen M., Foster S. \& Reid J.B. 2008. Seabirds as indicators of the marine environment. ICES Journal of Marine Science 65 , 1520-1526, doi: 10.1093/icesjms/fsn 155.
Piatt I.J.F. \& Sydeman W.J. 2007. Seabirds as indicators of marine ecosystems. Marine Ecology Progress Series 352, 199204, doi: 10.3354/meps07070.

SDJV (Sea Duck Joint Venture) 2018. Long-tailed duck (oldsquaw). Accessed on the internet at https://seaduckjv.org/ meet-the-sea-ducks/long-tailed-duck-oldsquaw/ on 30 January 2019.

Steenweg R.J., Crossin G.T., Kyser T.K., Merkel F.R., Gilchrist H.G., Hennin H.L., Robertson G.J., Provencher J.F., Mills Flemming J. \& Love O.P. 2017. Stable isotopes can be used to infer the overwintering locations of prebreeding marine birds in the Canadian Arctic. Ecology and Evolution 7, 87428752, doi: 10.1002/ece3.3410.

Thomas L., Buckland S.T., Rexstad E.A., Laake J., Strindberg S., Hedley S.L., Bishop J.R.B., Marques T.A. \& Burnham K.P. 2010. Distance software: design and analysis of distance sampling surveys for estimating population size. Journal of Applied Ecology 47, 5-14, doi: 10.1111/j.1365-2664.2009.01737.x.

Valeur H.H., Hansen C., Hansen K.Q., Rasmussen L. \& Thingvad L. 1996. Weather, sea and ice conditions in eastern Baffin Bay, offshore northwest Greenland. A review. Technical Report 96-12. Copenhagen: Danish Meteorological Institute.

Wegeberg S., Southcott C., Aastrup P., Hansen A.M. \& Tejsner P. 2018. Non-living resources. In A. Mosbech et al. (eds.): Adaptation actions for a changing Arctic: perspectives from the Baffin Bay/Davis Strait region. Pp. 201-219. Oslo: Arctic Monitoring and Assessment Programme. 